\title{
Mycosphaerangium and Neomelanconium (Cenangiaceae) are closest relatives: phylogenetic relationships, morphology and a new species
}

\author{
Hermann Voglmayr $r^{1,2}$ (D) Walter M. Jaklitsch ${ }^{1,2} \cdot$ Salvador Tello $^{3}$ \\ Received: 24 July 2020 / Revised: 15 September 2020 / Accepted: 21 September 2020 \\ (C) The Author(s) 2020
}

\begin{abstract}
Based on molecular phylogenetic analyses of a multigene matrix of partial nuSSU-ITS-LSU rDNA, RPB1, RPB2 and TEF1 sequences and by morphological evidence, the genus Mycosphaerangium is shown to be the closest relative of Neomelanconium, and confirmed to be a member of the Cenangiaceae (Leotiomycetes). While Mycosphaerangium and Neomelanconium share many traits like similar conidia, conidiogenesis, asci and ascospores, their apothecia differ particularly in excipular features and are therefore recognized as distinct genera. Mycosphaerangium tiliae, described from North America, is excluded from the genus but shown to represent the sexual morph of the European Neomelanconium gelatosporum, and it is therefore synonymized with the latter. Based on morphology, Neomelanconium deightonii is assumed to be congeneric with Neomelanconium gelatosporum, and it is lectotypified. Dermatea tetraspora and Phaeangium magnisporum, the basionyms of Mycosphaerangium tetrasporum and M. magnisporum, respectively, are lectotypified as well, and for M. tetrasporum, the asexual morph is recorded for the first time. Mycosphaerangium quercinum sp. nov. is described as a new species from various Quercus hosts in Europe, where it is shown to be widely distributed. It morphologically and ecologically closely resembles the North American M. tetrasporum, but differs in paraphysis and ascospore morphology and by croziers at its ascus base. The three accepted species of Mycosphaerangium and the two of Neomelanconium are described and illustrated. Mycosphaerangium magnisporum, M. quercinum and M. tetrasporum are recorded to be constantly associated with species of Coryneum, indicating a fungicolous habit, but no evidence for fungal associations has been found in Neomelanconium deightonii and N. gelatosporum.
\end{abstract}

Keywords Ascomycota $\cdot$ Helotiales $\cdot$ Incertae sedis $\cdot$ Leotiomycetes $\cdot$ Melanconium $\cdot$ Molecular phylogeny $\cdot$ Systematics · Taxonomy $\cdot 1$ new species

\section{Introduction}

The anamorph genus Melanconium is morphologically characterized by unicellular ellipsoid brown conidia produced in

Section Editor: Roland Kirschner

Hermann Voglmayr

hermann.voglmayr@univie.ac.at

1 Institute of Forest Entomology, Forest Pathology and Forest Protection, Department of Forest and Soil Sciences, BOKU-University of Natural Resources and Life Sciences, Peter-Jordan-Straße 82, 1190 Vienna, Austria

2 Department of Botany and Biodiversity Research, University of Vienna, Rennweg 14, 1030 Wien, Austria

3 Jaén, Spain acervuli (Sutton 1964). Melanconis, a diaporthalean genus, was commonly accepted to be its asexual morph (Barr 1978). However, as outlined in Rossman et al. (2015) and Jaklitsch and Voglmayr (2020), the generic concept of Melanconium and the true identity of its generic type, M. atrum, are obscure, and therefore the well-defined Melanconis was protected over Melanconium (Turland et al. 2018, Appendix III). Through its history, numerous species have been described within Melanconium, making it a heterogeneous assemblage. Therefore, many Melanconium species have been subsequently transferred to other genera such as Arthrinium, Greeneria and Harknessia (Rossman et al. 2015). Likewise, also the large genus Melanconis has been shown to be polyphyletic, and it has been restricted to eight closely related species (Jaklitsch and Voglmayr 2020).

Melanconium gelatosporum was described by Zimmermann (1913) from Tilia, for which Petrak (1940) 
established the new genus Neomelanconium. Subsequently, Petrak (1954) and recently Wijayawardene et al. (2016) added two additional species, $N$. deightonii and $N$. spartii, respectively. In the original description, Zimmermann (1913) supposed diaporthalean affinities, but Petrak $(1940,1954)$ considered it to be the asexual morph of a member of Massariaceae (Dothideomycetes). Until recently, the systematic affiliation of the type species remained unresolved and was based solely on morphological observations. Nowadays, the genus is classified as Pezizomycotina incertae sedis in Index Fungorum (accessed 14 Sep. 2020). However, Crous et al. (2019) published sequence data for $N$. gelatosporum which revealed a phylogenetic affiliation with Cenangiaceae (Leotiomycetes). Also, they decided to place $N$. spartii in a new genus Pseudomelanconium based on morphological differences, albeit no sequence data were available for the latter. In lack of type studies and sequence data, the status of the third species, $N$. deightonii, remained unclear. No sexual morph has been published for any Neomelanconium species.

The sexual morph genus Mycosphaerangium was established by Verkley (1999) for three species originally described in the genus Sphaerangium (Seaver 1951), with M. tetrasporum as type species. This is a later homonym of the moss genus Sphaerangium Schimp. The three species share many traits: erumpent apothecia, dark brown to black hymenium, a lighter brown coloured excipulum, thin-walled asci with a broadly rounded apex without a visible apical apparatus, and large, subglobose to ellipsoid, dark brown ascospores surrounded by a distinct refractive, hyaline gel sheath (Verkley 1999). Due to the peculiar morphology and the lack of fresh material, Verkley (1999) classified Mycosphaerangium as Helotiales incertae sedis, which was subsequently commonly followed by other authors (e.g. Jaklitsch et al. 2016). No sequence data have yet become available for the genus, and its systematic affinities within Leotiomycetes are currently unclear.

Several collections from corticated Quercus twigs made by the first author revealed an apparently undescribed coelomycete resembling the genus Neomelanconium. Concurrently, the third author made several holomorphic collections of a discomycete on Quercus in Spain which showed close affinities to the North American Mycosphaerangium tetrasporum. A morphological comparison of the asexual morphs of all these collections revealed that they fully matched, which was further confirmed by sequence data from cultures obtained from sexual and asexual morphs. This led us to initiate a detailed study on the genera Neomelanconium and Mycosphaerangium. Fresh material of Neomelanconium gelatosporum was collected for morphological studies, pure culture isolation and sequencing. Type material of all three Mycosphaerangium and of the two Neomelanconium species was reviewed. In addition, multigene phylogenetic analyses were performed to solve the placement of these genera.

\section{Materials and methods}

\section{Field survey, sample collection and sample sources}

During the period 2015-2020, recently shed or still attached dead, corticated twigs of Quercus spp. and Tilia spp. were collected, examined for the presence of fungi of interest and air dried for subsequent morphological analysis, pure culture isolation and molecular studies. Material was collected in Austria, Greece, Italy and Spain mostly in light, mixed deciduous forests, occasionally on solitary trees in alleys or parks. Typical habitats are shown in Fig. 1. After processing, specimens were deposited in the fungaria of the University of Vienna (WU) and of the Consejería de Medio Ambiente (Junta de Andalucía), Sevilla (JA-CUSSTA).

In addition to fresh collections, specimens of Mycosphaerangium and Neomelanconium spp. were received on loan from herbaria FH, GAM, GZU, NY, and $\mathrm{W}$ and morphologically investigated. Details of the specimens used for morphological investigations are listed in the Taxonomy section; herbarium acronyms are according to Thiers (2020), and citation of exsiccatae follows Triebel and Scholz (2020).

\section{Morphological observations}

Stereomicroscopy photographs were captured with a Nikon SMZ 1500 stereomicroscope equipped with a Nikon DS-U2 digital camera or with a Sony Cyber-shot DSC-HX100V camera mounted in one of the oculars of a binocular lens, using a LED lamp for lighting. For certain images of ascomata, the stacking software Zerene Stacker version 1.04 (Zerene Systems LLC, Richland, WA, USA) was used.

For light microscopy, fresh collections were rehydrated and examined according to "vital taxonomy" in the sense of Baral (1992). Hand sections of ascomata and conidiomata were made using a razor blade and the following reagents were used as mounting media: tap water, $3 \% \mathrm{KOH}$, Congo red, Lugol's reagent (IKI, with 3\% KJ and 1\% iodine) and Indian ink. Slides were examined and photographed using a Zeiss Axio Imager.A1 (Zeiss, Jena, Germany) microscope equipped with a Zeiss Axiocam 506 colour digital camera or a Canon EOS 40D camera installed on an OPTIKA B-350 microscope. Measurements were done with the NIS-Elements D v.3.0 or Zeiss ZEN Blue Edition software packages. Measurements are reported as maxima and minima in parentheses and the range representing the mean plus and minus the standard deviation of a number of measurements given in parentheses; in addition, means of measurements (Me) and of $1 / w$ ratios (Qe) are given for ascospores and conidia. 
Fig. 1 Typical habitats of Mycosphaerangium quercinum $(\mathbf{a}-\mathbf{c})$ and Neomelanconium gelatosporum (d)
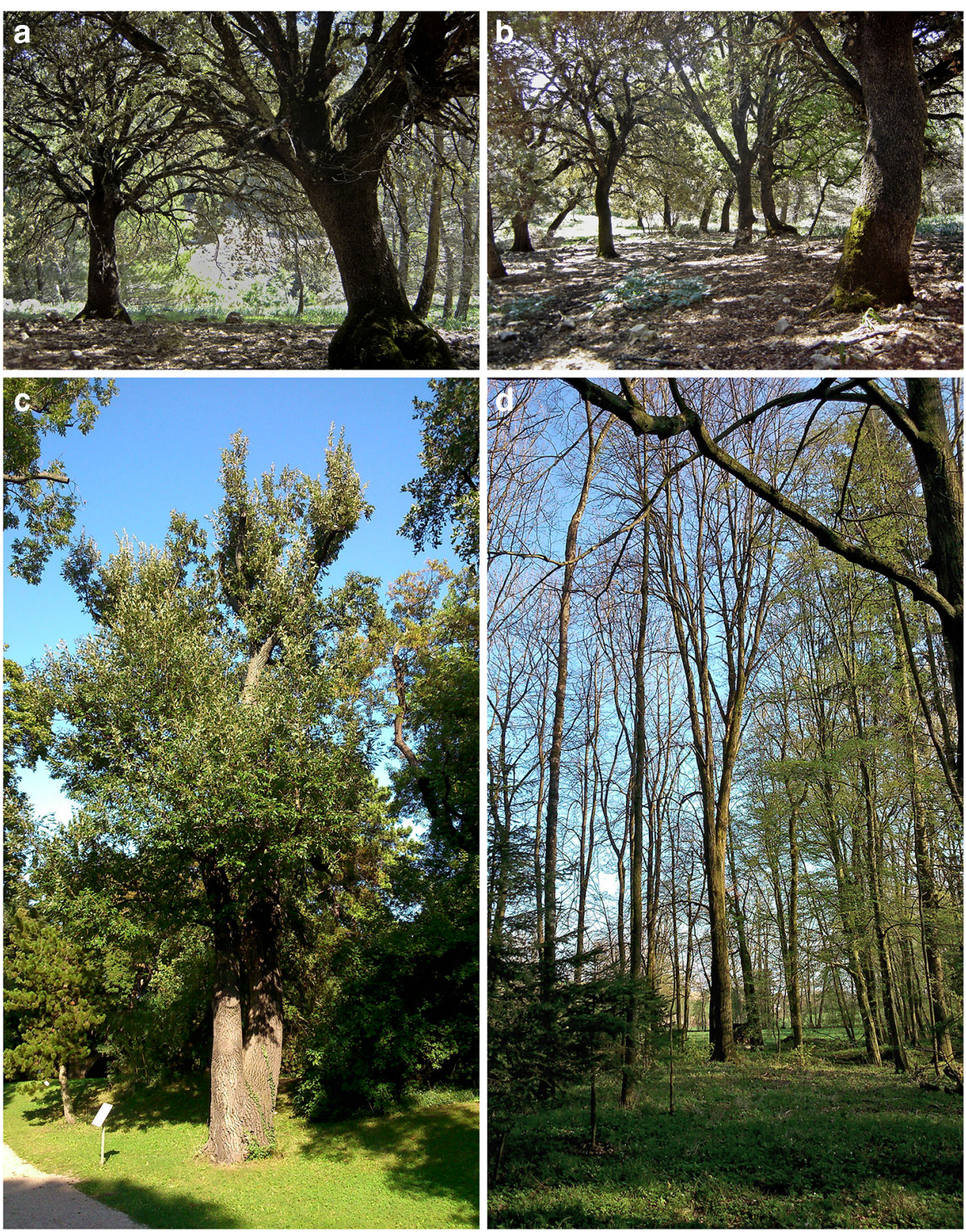

\section{Pure culture isolation}

Mature conidiomata or apothecia were horizontally or vertically cut using a sterile razor blade and the surrounding host tissue was removed. Subsequently, the sections were transferred to a sterile drop of water on a microscope slide, torn apart with a forceps to release the conidia or the ascospores, and the suspension was pipetted on $2 \%$ corn meal agar (CMA, Sigma-Aldrich) supplemented with $2 \% w / v$ dextrose (CMD) or $2 \%$ malt extract agar (MEA) plates supplemented with $200 \mathrm{mg} / \mathrm{l}$ penicillin $\mathrm{G}$ and streptomycin sulphate (SigmaAldrich, St. Louis, MO) and incubated at room temperature. As the conidia and ascospores germinated slowly, the isolation plates were regularly checked for contaminations, which were removed. Germinated conidia or ascospores were then transferred to $2 \%$ CMD or $2 \%$ MEA plates, which were sealed with laboratory film and incubated at $22{ }^{\circ} \mathrm{C}$. Cultures were deposited at the Westerdijk Fungal Biodiversity Centre, Utrecht, The Netherlands (CBS culture collection).

\section{DNA extraction, PCR and sequencing}

Growth of liquid cultures and extraction of genomic DNA was done according to Voglmayr and Jaklitsch (2011), using the DNeasy Plant Mini Kit (QIAgen GmbH, Hilden, Germany). Six loci (ITS, LSU, and SSU rDNA, RPB1, RPB2, TEF1) were amplified. For details on the primers and annealing temperatures used for PCR and sequencing, see Table 1. PCR products were 
Table 1 Primers used to amplify and sequence the nuclear internal transcribed spacer (ITS), large subunit (LSU) and small subunit (SSU) rDNA regions, the RNA polymerase II largest $(R P B 1)$ and second largest $(R P B 2)$ subunit genes and the translation elongation factor 1- $\alpha$ (TEF1) gene

\begin{tabular}{|c|c|c|c|c|c|}
\hline Gene & Primer & Sequence $\left(5^{\prime}-3^{\prime}\right)$ & Direction & Annealing $t\left({ }^{\circ} \mathrm{C}\right)$ & Reference \\
\hline \multicolumn{6}{|c|}{ ITS-LSU } \\
\hline & V9G & TTAAGTCCCTGCCCTTTGTA & Forward & \multirow[t]{5}{*}{55} & Hoog and Gerrits van den Ende (1998) \\
\hline & LR5 & TACTTGAAGGAACCCTTACC & Reverse & & Vilgalys and Hester (1990) \\
\hline & LR2R-A ${ }^{1}$ & CAGAGACCGATAGCGCAC & Forward & & Voglmayr et al. (2012) \\
\hline & $\mathrm{LR}^{1}$ & CCGTGTTTCAAGACGGG & Reverse & & Vilgalys and Hester (1990) \\
\hline & ITS $4^{1}$ & TCCTCCGCTTATTGATATGC & Reverse & & White et al. (1990) \\
\hline \multicolumn{6}{|l|}{ SSU } \\
\hline & SL1 & TGGTTGATCCTGCCAGTA & Forward & \multirow[t]{3}{*}{53} & Voglmayr and Jaklitsch (2011) \\
\hline & NS24mod & GAAACCTTGTTACGACTTTTAC & Reverse & & White et al. (1990) \\
\hline & NS1088 ${ }^{1}$ & TGATTTCTCGTAAGGTGCCG & Reverse & & Kauff and Lutzoni (2002) \\
\hline \multicolumn{6}{|l|}{$R P B 1$} \\
\hline & RPB1-Af & GARTGYCCDGGDCAYTTYGG & Forward & \multirow[t]{2}{*}{55} & Stiller and Hall (1997) \\
\hline & RPB1-6R1asc & ATGACCCATCATRGAYTCCTTRTG & Reverse & & Hofstetter et al. (2007) \\
\hline \multicolumn{6}{|l|}{$R P B 2$} \\
\hline & $\mathrm{dRPB} 2-5 \mathrm{f}$ & GAYACNGAYGAYCGWGAYCAYTTYGG & Forward & \multirow[t]{2}{*}{52} & Voglmayr et al. (2016) \\
\hline & dRPB2-7r & AANCCCATDGCYTGYTTDCCCAT & Reverse & & Voglmayr et al. (2016) \\
\hline \multicolumn{6}{|l|}{ TEF1 } \\
\hline & $\mathrm{EF} 1-728 \mathrm{~F}$ & CATCGAGAAGTTCGAGAAGG & Forward & \multirow[t]{3}{*}{55} & Carbone and Kohn (1999) \\
\hline & EF1-2218R & TACTTGAAGGAACCCTTACC & Reverse & & Carbone and Kohn (1999) \\
\hline & TEF1_INTF ${ }^{1}$ & CCGTGAYTTCATCAAGAACATG & Forward & & Jaklitsch (2009) \\
\hline & TEF1_INTF & CCGTGAYTTCATCAAGAACATG & Forward & \multirow[t]{2}{*}{55} & Jaklitsch (2009) \\
\hline & EF1-2218R & TACTTGAAGGAACCCTTACC & Reverse & & Carbone and Kohn (1999) \\
\hline
\end{tabular}

${ }^{1}$ Internal primers used only for sequencing

purified using an enzymaticPCR cleanup (Werle et al. 1994) as described in Voglmayr andJaklitsch (2008). DNA was cyclesequenced using the ABI PRISM Big Dye Terminator Cycle Sequencing Ready Reaction Kit v. 3.1 (Applied Biosystems, Warrington) and the PCR primers; in addition, for some loci, internal primers were used (see Table 1). Sequencing was performed on an automated DNA sequencer (ABI 3730xl Genetic Analyzer, Applied Biosystems).

\section{Phylogenetic analyses}

For phylogenetic analyses, a matrix of aligned nucleotide sequences from six different phylogenetic markers (ITS, LSU, and SSU rDNA, RPB1, RPB2, TEF1) was produced. Sequences obtained in the present study were aligned to selected GenBank sequences of Cenangiaceae, Rutstroemiaceae and Sclerotiniaceae from Pärtel et al. (2017) and Johnston et al. (2019) and complemented with a few additions from GenBank. Five species of Chlorociboria (Chlorociboriaceae) were selected as outgroup according to Johnston et al. (2019). Sequences were aligned with the server versions of MAFFT (Katoh et al. 2002; http://www.ebi.ac.uk/Tools/mafft (Madeira et al. 2019), https://mafft.cbrc.jp/alignment/server (Katoh et al.
2019)) and subsequently checked, trimmed and refined using BioEdit version v. 7.0.9.0 (Hall 1999), removing excessive leading and trailing gap regions and adjusting the proteincoding gene alignments according to the correct amino acid reading frame. The combined sequence matrix contained 6677 nucleotide positions (555 from ITS, 1299 from LSU, 1633 from SSU, 1104 from $R P B 1,1076$ from $R P B 2,1010$ from $T E F 1$ ). GenBank accession numbers of the sequences included in the phylogenetic analyses are given in Table 2; the species classification follows Galán et al. (2015), Johnston et al. (2019) and Perić et al. (2019).

Maximum likelihood (ML) analyses were performed with RAxML (Stamatakis 2006) as implemented in raxmlGUI 1.3 (Silvestro and Michalak 2012), using the ML + rapid bootstrap setting and the GTRGAMMA substitution model with 1000 bootstrap replicates. The matrix was partitioned for the individual gene regions, with separate substitution model parameters implemented.

Maximum parsimony (MP) analyses were performed with PAUP v. 4.0a167 (Swofford 2002), using 1000 replicates of heuristic search with random addition of sequences and subsequent TBR branch swapping (MULTREES option in effect, steepest descent option not in effect). All molecular characters 


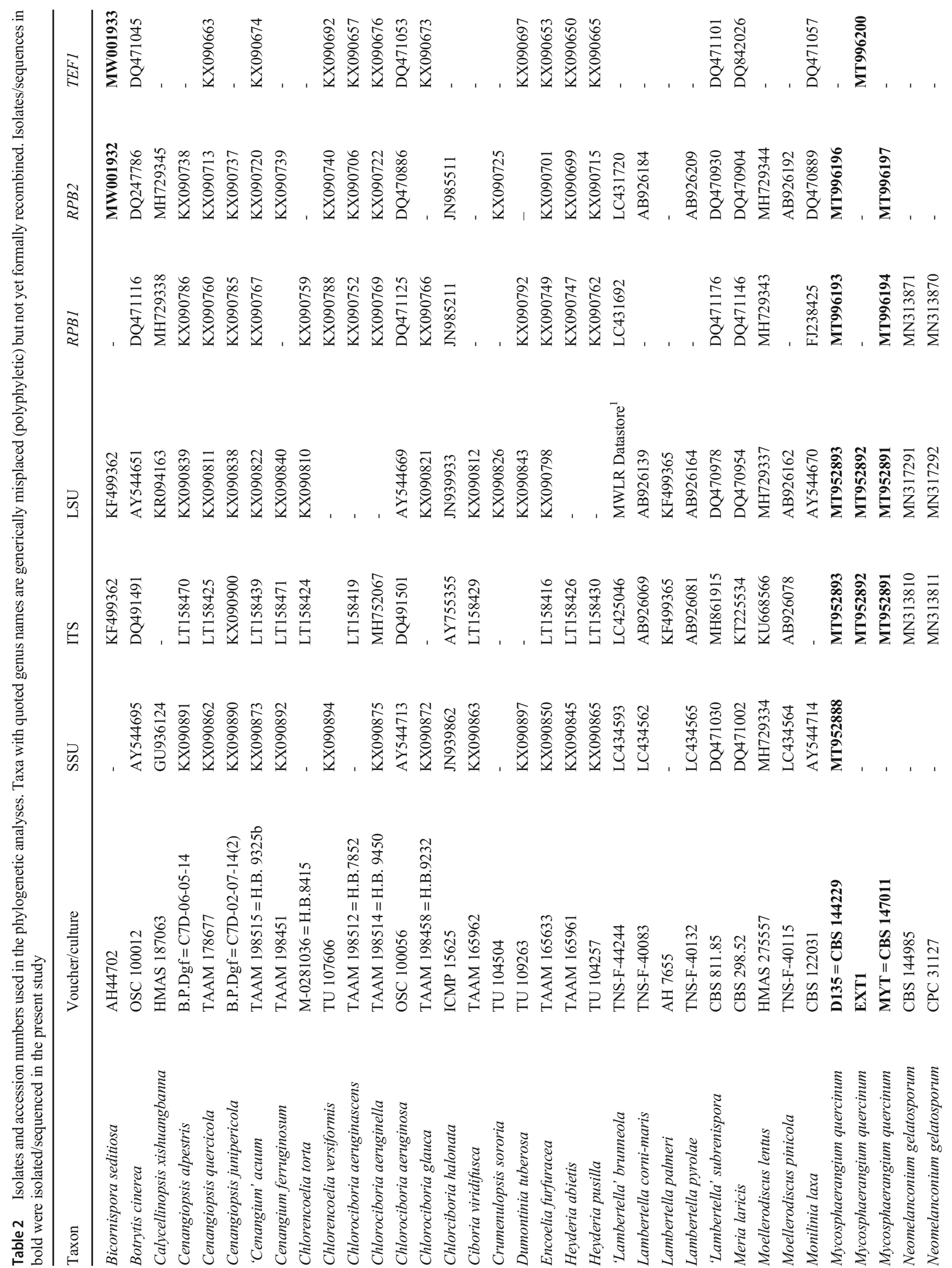




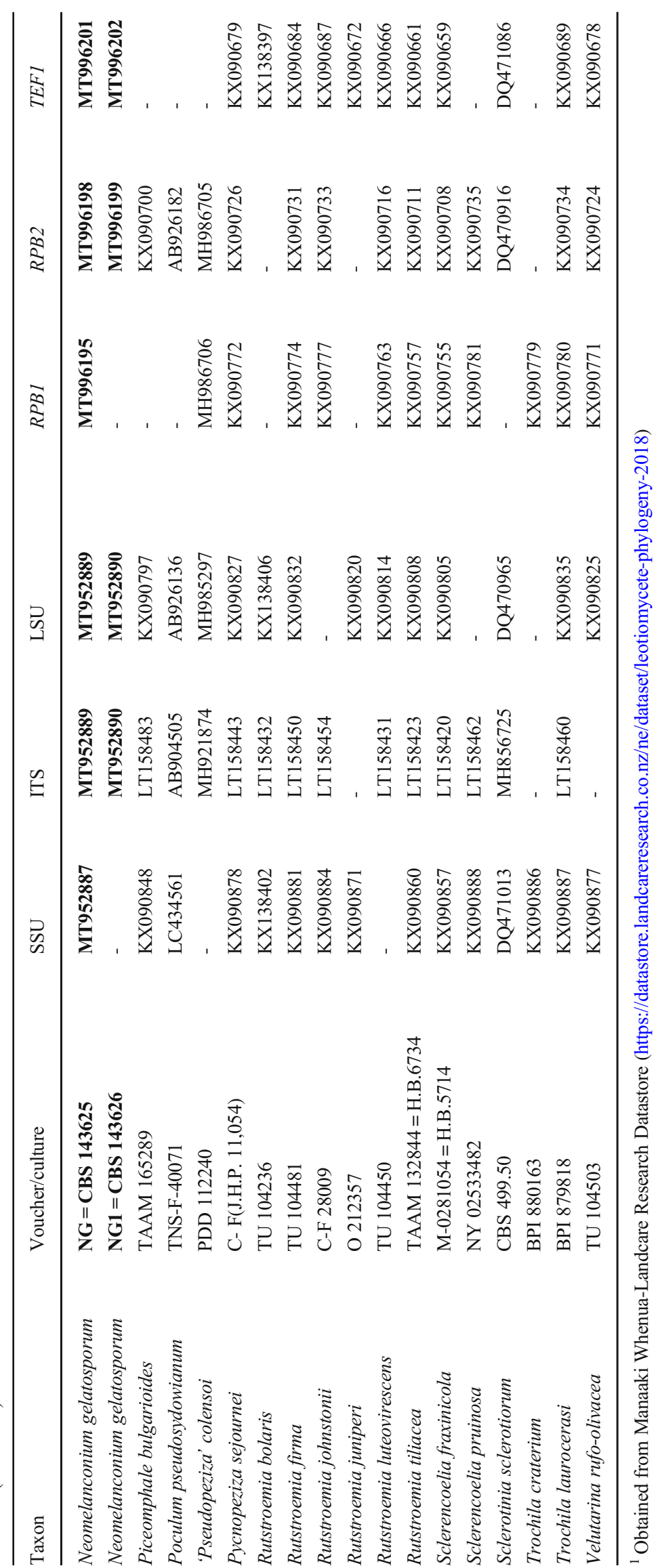


were unordered and given equal weight; analyses were performed with gaps treated as missing data; the COLLAPSE command was set to NO. Bootstrap analysis with 1000 replicates was performed in the same way, but using 10 rounds of random sequence addition and subsequent TBR branch swapping during each bootstrap replicate.

Bootstrap support below $70 \%$ was considered low, between 70 and $90 \%$ moderate, above $90 \%$ high and $100 \%$ maximum.

\section{Results}

\section{Culture characteristics}

Culture images of Mycosphaerangium quercinum and Neomelanconium gelatosporum grown on 2\% CMD and 2\% MEA are shown in Fig. 2. Culture descriptions are given under the respective species.

\section{Molecular phylogeny}

Of the 6677 nucleotide positions, 1882 were parsimony informative (238 from ITS, 198 from LSU, 140 from SSU, 526 from $R P B 1,493$ from $R P B 2$ and 287 from TEF1). The parsimony analyses revealed $1 \mathrm{MP}$ tree 10,574 steps long (not shown). The best tree revealed by RAxML $(-\ln =54,940.906)$ is shown as phylogram in Fig. 3. Except for a few deeper nodes, topologies of the ML tree were largely compatible with the MP tree. Tree topologies of our phylogenetic analyses agree well with those of Johnston et al. (2019). In the phylogenetic analyses, the Cenangiaceae clade and the Rutstroemiaceae-Sclerotiniaceae clade receive maximum support. Within the latter, the Sclerotiniaceae are resolved as a highly supported clade, but they are embedded within a paraphyletic Rutstroemiaceae, which consists of three highly supported subclades. Within Cenangiaceae, Mycosphaerangium quercinum and Neomelanconium gelatosporum are sister species with maximum support, and the sister group relationship of the Mycosphaerangium-Neomelanconium clade with Trochila craterium is moderately supported. As previously reported (e.g. Pärtel et al. 2017, Johnston et al. 2019), several genera like Cenangium, Lambertella, Moellerodiscus and Trochila are polyphyletic, indicating that the morphological characters currently used for generic circumscription do not reflect phylogenetic relationships, necessitating additional morphological and molecular investigations to reach more appropriate generic concepts within Helotiales.

\section{Taxonomy}

Mycosphaerangium Verkley, Stud. Mycol. 44: 156. 1999.

= Sphaerangium Seaver, North American Cup-fungi, (Inoperculates) (New York): 308. 1951. Nom. illegit., Art. 53.1.

Type species: Mycosphaerangium tetrasporum (Ellis) Verkley.

Sexual morph apothecial, erumpent through bark, solitary or in groups, sessile to subsessile; basal stroma absent. Recpetacle paler than the disc, beige, orange to dark brown, with raised, rim-like margins, curved inward when dry. Disc circular, elliptic to irregularly polyangular, concave to plane, dark brown to black, rough. Paraphyses embedded in hymenial gel, longer than the asci, filiform, septate, simple or branched, sometimes anastomosing, with hyaline to brownish, slightly to distinctly swollen or irregularly sinuousknobby tips, refractive vacuolar bodies (VBs) absent. Asci cylindrical-clavate, thin-walled, unitunicate, with broadly rounded to subtruncate apex without a distinct apical apparatus and opening by an apical rupture, with 4 uniseriately
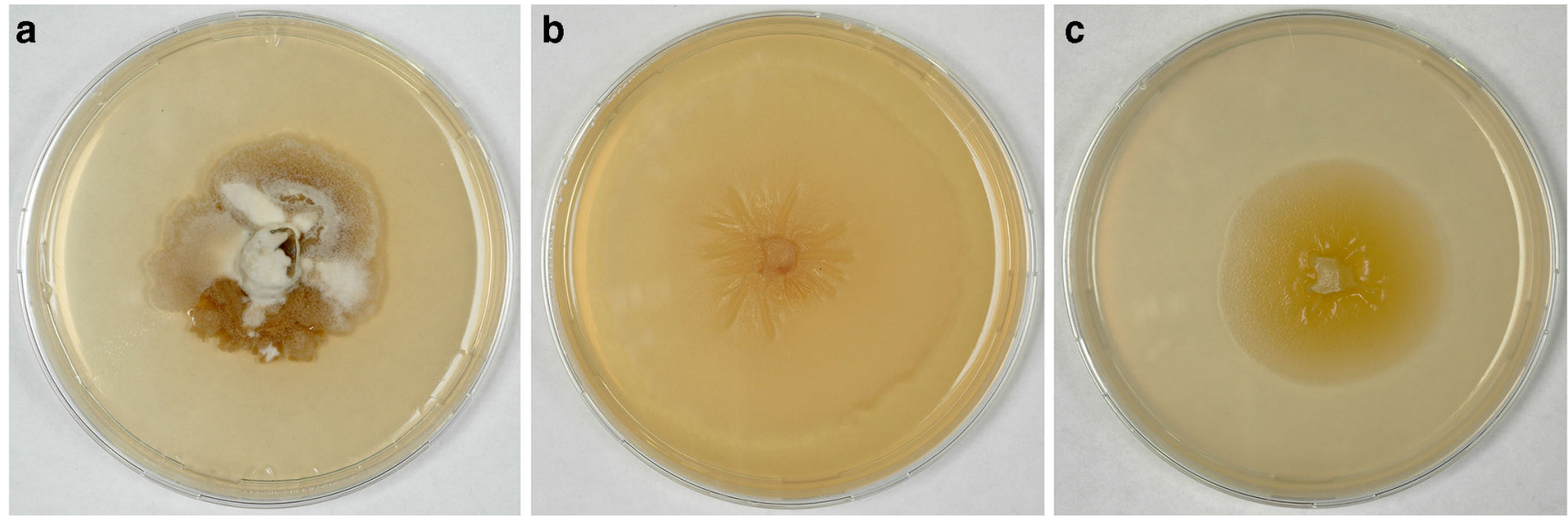

Fig. 2 Cultures $\left(22^{\circ} \mathrm{C}\right)$. (a) Mycosphaerangium quercinum D135 on CMD after 3 months. (b, c) Neomelanconium gelatosporum NG on MEA (b) and CMD (c) after 2 months 
Fig. 3 Phylogram of the best ML trees $(-\operatorname{lnL}=54940.906)$ revealed by RAxML from an analysis of the combined SSU-ITS-LSU$R P B 1-R P B 2-T E F 1$ matrix of selected Helotiales, showing the phylogenetic position of Mycosphaerangium and Neomelanconium within Cenangiaceae. Strains in bold were sequenced in the current study. ML and MP bootstrap supports above $50 \%$ are given at the first and second positions, respectively, above or below the branches

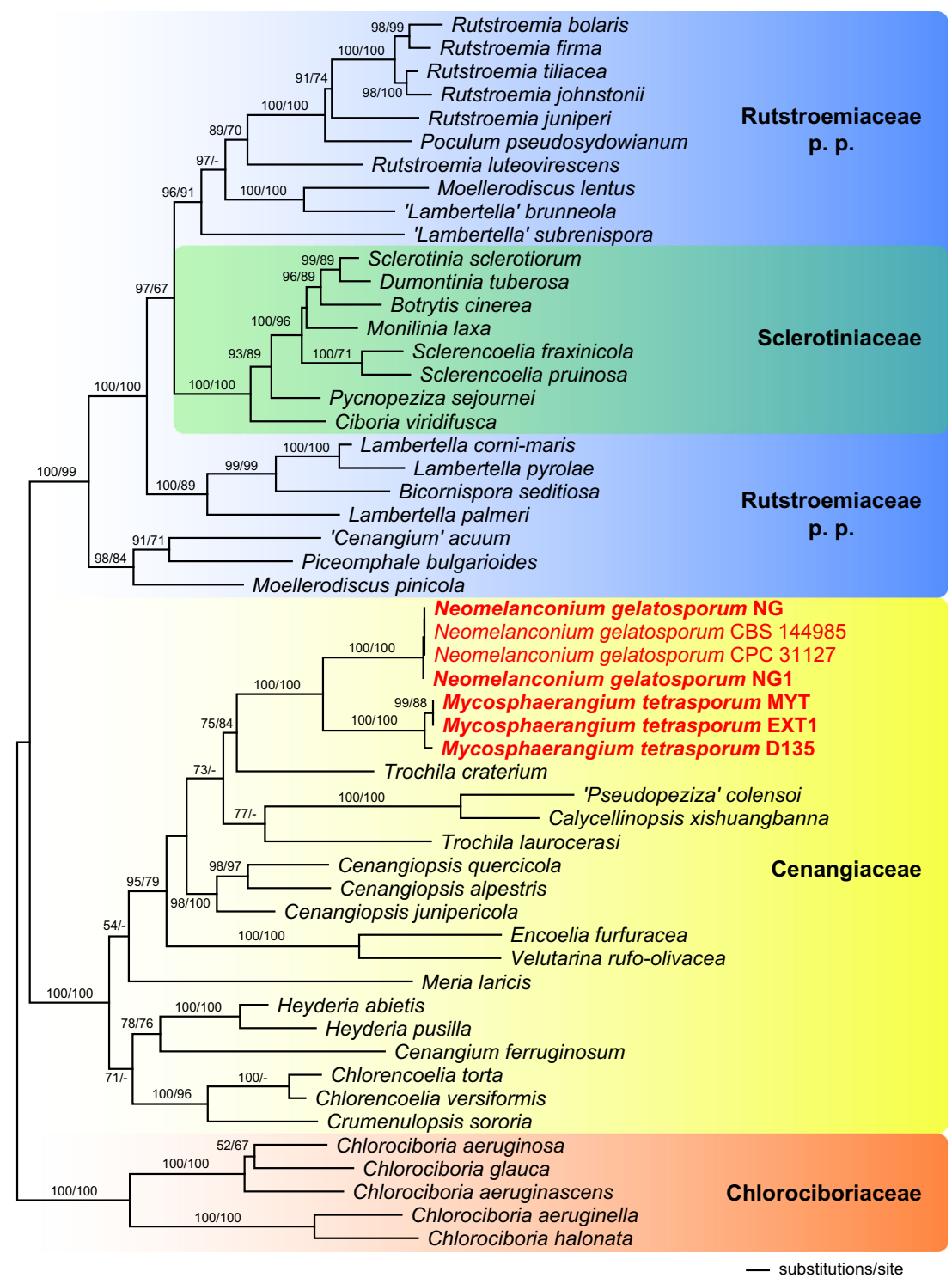

arranged ascospores. Ascospores dark brown, aseptate, subglobose or ellipsoid, with a thick, dark brown, minutely to distinctly warted wall, surrounded by a prominent hyaline gelatinous sheath rapidly expanding in water.

Asexual morph acervular, usually conspicuous due to black, glossy, effused conidial masses, associated with conidiomata or stromata of Coryneum spp. Conidiomata subperidermal, not to slightly elevating the bark, solitary, scattered, lenticular, with thin, whitish pseudoparenchymatous base. Conidiophores emerging from a pseudoparenchymatous base, reduced to the conidiogenous cells. Conidiogenous cells percurrent, smooth, cylindrical to filiform, hyaline, commonly turning yellowish-brown with age, with a single, often indistinct annellation. Conidia dark brown, aseptate, subglobose, broadly ellipsoid, ovoid to pyriform, apex broadly rounded, base truncate, thick-walled, guttulate, usually with one large and numerous small guttules, with smooth to finely verruculose wall, surrounded by a prominent hyaline gelatinous sheath rapidly expanding in water.

Notes: No asexual morph has been known for Mycosphaerangium until this study, a connection which is here confirmed by morphological and molecular phylogenetic data. The three species here accepted within the genus, M. magnisporum, M. quercinum and M. tetrasporum, are closely associated with Coryneum conidiomata or stromata, indicating a fungicolous ecology. Mycosphaerangium tiliae is removed from the genus based on apothecial morphology, differing by 8 -spored asci and by marginal, inversely stellate excipular teeth with a textura prismatica-porrecta and covered by an external layer of white crystals; $M$. tiliae is synonymized with Neomelanconium gelatosporum (see below).

Mycosphaerangium magnisporum (E.K. Cash) Verkley, Stud. Mycol. 44: 157. 1999. Figure 4. 

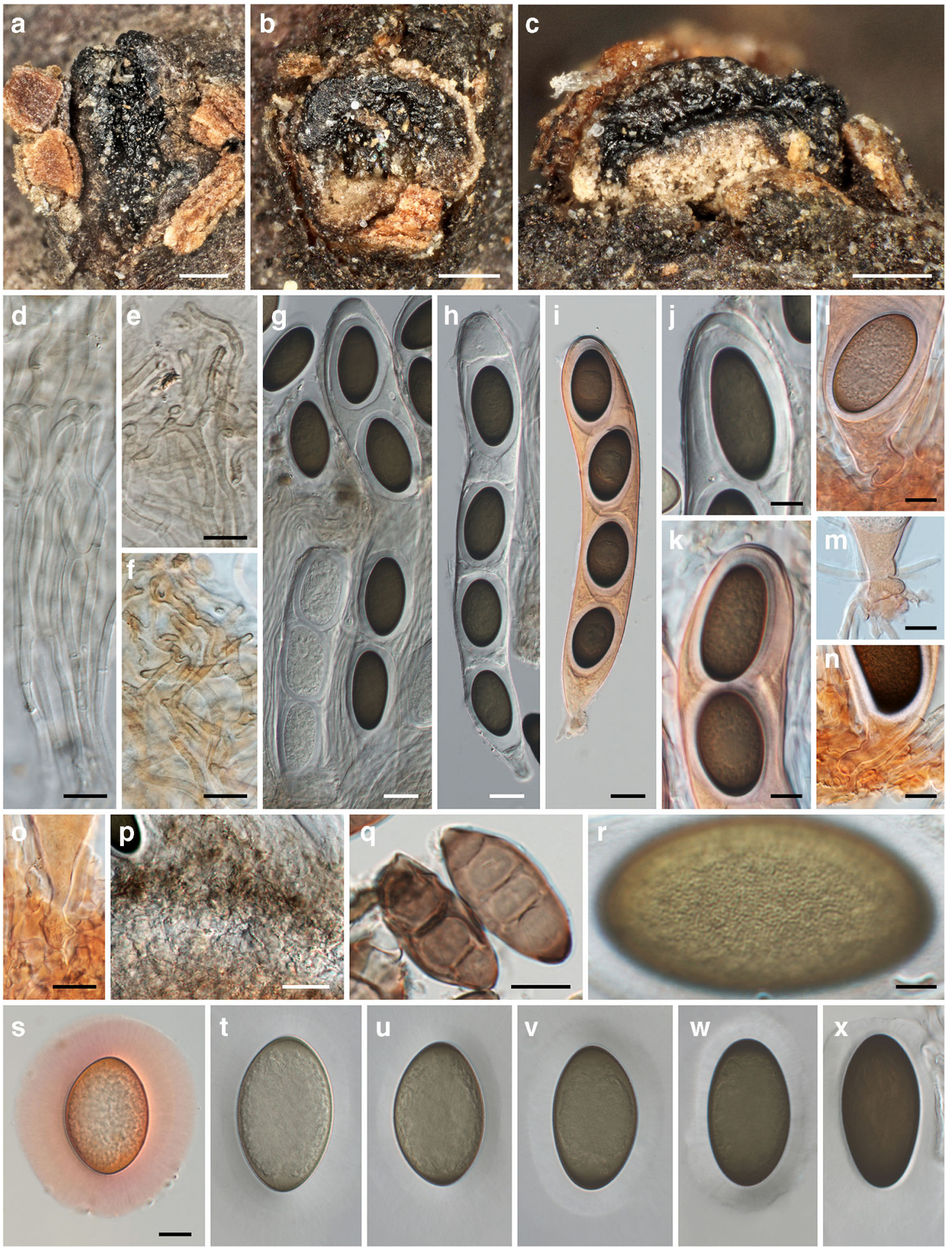

Fig. 4 Mycosphaerangium magnisporum, sexual morph ((a) NY 02975297, isotype; (b-e, g, h, j, p, r, t-x) NY 02975298, lectotype; (f, $\mathbf{i}, \mathbf{k}-\mathbf{0}, \mathbf{q}, \mathbf{s}) \mathrm{FH}$ 00965165, isotype). (a, b) Apothecia in face view. (c) Apothecium in side view. (d) Septate anastomosing paraphyses. (e, f) Branched paraphysis tips with brown, finely verruculose encrustation. (g-i) Asci with four ascospores surrounded by thick gelatinous sheath.

(j, k) Ascus apices. (I-o) Ascus bases with simple septa. (p) Subhymenium. (q) Conidia of Coryneum betulinum associated with apothecia. ( $\mathbf{r}-\mathbf{x})$ Ascospores with swelling gelatinous sheath (in (r) showing fine verrucae on inner ascospore wall, (s) immature). All mounts dead and in $3 \% \mathrm{KOH}$, except (f, i, k-o, s) in Congo red. Scale bars: $(\mathbf{a}-\mathbf{c}) 200 \mu \mathrm{m} ;(\mathbf{d}-\mathbf{f}, \mathbf{j}-\mathbf{o}, \mathbf{q}, \mathbf{s}-\mathbf{x}) 10 \mu \mathrm{m} ;(\mathbf{g}-\mathbf{i}, \mathbf{p}) 20 \mu \mathrm{m} ;(\mathbf{r}) 5 \mu \mathrm{m}$ 
Basionym: Phaeangium magnisporum E.K. Cash, J. Wash. Acad. Sci. 30: 304. 1940.

三Sphaerangium magnisporum (E.K. Cash) Seaver, North American Cup-fungi, (Inoperculates) (New York): 309. 1951.

Sexual morph: Apothecia 1-1.5-mm diam, erumpent from bark, solitary or in groups of 2-3, sessile, without a basal stroma, circular to elliptic, plane to concave, often compressed and contorted, black. Receptacle finely scaly with the outer surface beige to medium brown, margin concolourous and slightly raised. Hymenium roughened, dark brown to black. Subhymenium made of subhyaline to brownish textura intricata. Paraphyses ca. 250-300 $\mu \mathrm{m}$ long, 1.5-3 $\mu \mathrm{m}$ wide, cylindrical, hyaline, septate, branched, slightly longer than the asci, with branched, densely interwoven, not to slightly inflated tips with brownish, finely verruculose encrustation. Asci $(195-) 210-275(-300) \times(30.5-) 34-41(-44) \mu \mathrm{m}(n=27)$, cylindrical, unitunicate, with rounded to subtruncate apex, inamyloid, without visible apical apparatus, containing 4 uniseriately arranged ascospores, base tapering, with simple septum. Ascospore dehiscence unknown. Ascospores $(37-) 40.5-46(-50) \times(18-) 21-25(-29) \mu \mathrm{m}, 1 / \mathrm{w}=(1.5-) 1.7-$ 2.1(-2.6), $\mathrm{Me}=43 \times 23 \mu \mathrm{m}, \mathrm{Qe}=1.9(n=103)$, ellipsoid, first hyaline, turning medium to dark brown when mature, with darker brown ends, containing a large globose oil drop, wall appearing smooth in profile view, inner wall finely verruculose, with a prominent refractive gelatinous sheath widely expanded after release.

Asexual morph: unknown.

Habitat: on dead corticated branches of Betula nigra, associated with effete conidiomata of Coryneum betulinum.

Distribution: only known from GA, southeastern USA.

Typification: USA, GA, Clarke, Athens, University of Georgia, Agricultural Campus, in bark of Betula nigra, 2 Mar. 1939, leg. G.E. Thompson \& J.H. Miller (NY 02975298, lectotype here designated; MBT393680; isotypes NY 02975297, BPI 665743, FH 00965165; sexual morph).

Additional specimen examined: USA, GA, Clarke, Athens, University of Georgia, Agricultural Campus, in bark of Betula nigra, 14 Feb. 1939, leg. G.E. Thompson (GAM 00010414; depauperate).

Notes: Mycosphaerangium magnisporum is so far only known from two sites in GA, USA (see https://mycoportal. org/). The type collection, investigated and described by Edith K. Cash at the USDA, Beltsville, USA, was distributed to several herbaria in the USA, of which we here select the copy NY 02975298 as lectotype. In addition, a specimen from the same locality but with an earlier collection date was received from GAM; although it is marked as co-type, it is not mentioned in the protologue and therefore does not qualify for a type. The specimens seen contain only few ascomata and are in rather poor condition. Most apothecia seem to have fallen off which is already mentioned in the original description (Cash 1940). To save material, microscopy of the specimens was kept to a minimum, and some characters like excipulum morphology could not be documented. No conidiomata were seen on the specimens. Like in $M$. quercinum and $M$. tetrasporum, the apothecia of $M$. magnisporum are associated with a Coryneum species; it could be identified as $C$. betulinum (Fig. 4q). Despite the lack of sequence data and conidiomata, morphology and ecology leave no doubt about its affiliation with Mycosphaerangium. It differs from the other species by distinctly longer, ellipsoid ascospores with darker brown ends and a different host.

Mycosphaerangium quercinum Voglmayr, Jaklitsch \& Tello, sp. nov. Figures 5 and 6.

MycoBank: MB 836870.

Etymology: referring to its Quercus hosts.

Diagnosis: Mycosphaerangium quercinum is distinguished from the other species of the genus mainly by irregularly sinuous-knobby paraphysis tips encrusted by amorphous, olive to reddish brown plaques.

Sexual morph: Apothecia (0.4-)0.9-2.5(-4)-mm diam $(n=$ 82 ), erumpent from bark, solitary or in groups of 2-5, sessile, without a basal stroma, first closed, later opening to form circular to irregular concave discs. Receptacle scaly with the outer surface dark orange- to red-brown, margin raised, slightly paler, smooth to slightly lacerate. Hymenium roughened, dark brown to black, sometimes with light brown scales at the margins. Ectal excipulum consisting of a (41-)45-150(165) $\mu \mathrm{m}$ thick layer, narrower at the margin, consisting of brown textura globulosa-angularis, cells at margin (4.5-)8.5-15(-21)- $\mathrm{mm}$ diam $(n=105)$. Medullary excipulum up to $700 \mu \mathrm{m}$ thick at the base, consisting of yellowish brown to subhyaline textura globulosa-angularis, intermingled with some textura prismatica, with oil drops. Subhymenium made of hyaline textura intricata of $(2.5-) 3.2-5.3(-8) \mu \mathrm{m}(n=57)$ wide hyphae with oil contents. Paraphyses ca. 165-205 $\mu \mathrm{m}$ long, (1.7-)2.2-3.3 $\mu \mathrm{m}$ wide, cylindrical, hyaline, septate, branched, with lipid content at least in their lower thirds, with irregularly sinuous-knobby tips widened to 3-6 $\mu \mathrm{m}$, paraphysis tips encrusted by amorphous, olive to reddish brown plaques, refractive vacuolar bodies (VBs) absent. Asci

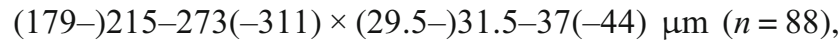
cylindrical-clavate, unitunicate, with rounded to subtruncate apex, inamyloid, without visible apical apparatus and with spore discharge by apical rupture (Fig. $5 \mathrm{~s}$ ), containing 4 uniseriately arranged ascospores, base tapering, with crozier (Fig. 5t). Ascospores (25-)28.5-33(-37) $\times(19-) 22.3-25(-$ 27.7) $\mu \mathrm{m}, 1 / \mathrm{w}=(1.1-) 1.2-1.4(-1.8), \mathrm{Me}=30.6 \times 23.7 \mu \mathrm{m}$, $\mathrm{Qe}=1.3(n=259)$, subglobose to ellipsoid, rarely with an apiculus on one end to $2.8 \mu \mathrm{m}$ long (Fig. 5y), first hyaline, turning pale brown and finally dark brown to nearly black when mature, containing a large globose oil drop (17.5-)18.5-20.7(-22.8)- $\mu \mathrm{m}$ diam $(n=67)$ and numerous small ones, with (0.9-)1.1-1.6(-1.7) $\mu \mathrm{m}$ thick, finely 

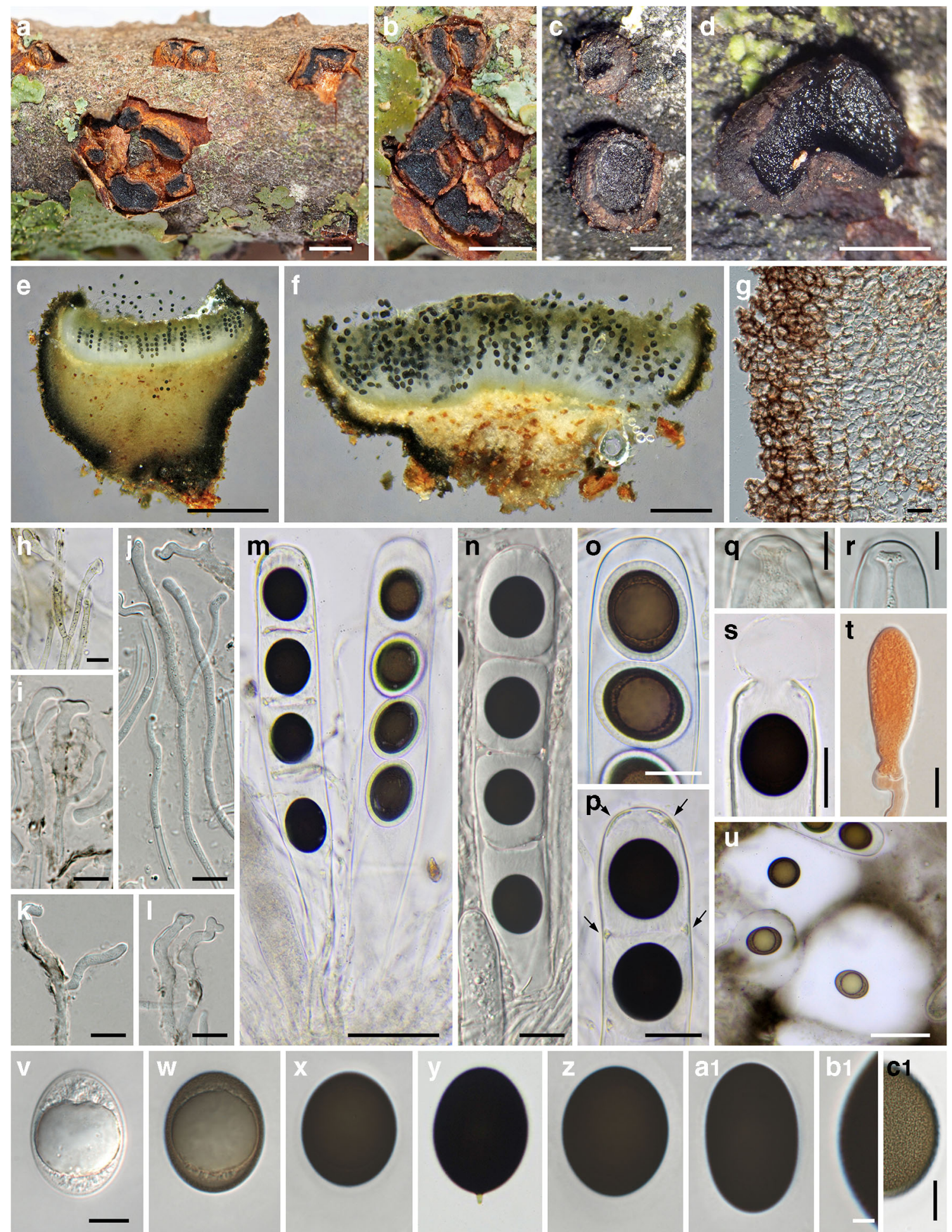

Fig. 5 Mycosphaerangium quercinum, sexual morph $((\mathbf{a}, \mathbf{b})$ S.T.13081703; (c-f, m-p, s, u) WU 40038; (g-l, q, r, t, v-x, z-c1) WU 40027, holotype; (y) JA-CUSSTA 8297). (a-d) Fresh apothecia in face view. (e, f) Apothecia in section. (g) Marginal excipulum (dead). (hl) Septate paraphyses with irregularly sinuous-knobby tips and brownish encrustation ((h) vital, (i-l) dead). (m, n) Asci with four ascospores surrounded by thick gelatinous sheath $((\mathbf{m})$ vital, (n) dead). (o-s) Ascus apices $((\mathbf{0}, \mathbf{p})$ vital, $(\mathbf{q}, \mathbf{r})$ dead, $(\mathbf{s})$ showing apical rupture; arrows in (p)

denoting membrane residues of broken expanded gel sheath). (t) Young ascus with basal crozier. (u-c1) Ascospores (in (u) showing widely expanded gelatinous sheath; in (y) with basal apiculus, (b1, c1) finely verruculose contours and wall in face view; (u-b1) vital, (c1) dead). All in water, except $(\mathbf{g}, \mathbf{i}-\mathbf{l}, \mathbf{n}, \mathbf{q}, \mathbf{r})$ in $3 \% \mathrm{KOH}$, (t) in Congo red, (u) in Indian ink. Scale bars: (a, b) $2 \mathrm{~mm}$; (c, d) $1 \mathrm{~mm}$; (e) $500 \mu \mathrm{m}$; (f) $200 \mu \mathrm{m}$; (g, n-p, s) $20 \mu \mathrm{m} ;(\mathbf{h}-\mathbf{l}, \mathbf{q}, \mathbf{r}, \mathbf{t}, \mathbf{v}-\mathbf{a} 1, \mathbf{c 1}) 10 \mu \mathrm{m} ;(\mathbf{m}, \mathbf{u}) 50 \mu \mathrm{m}$; (b1) $2 \mu \mathrm{m}$ 


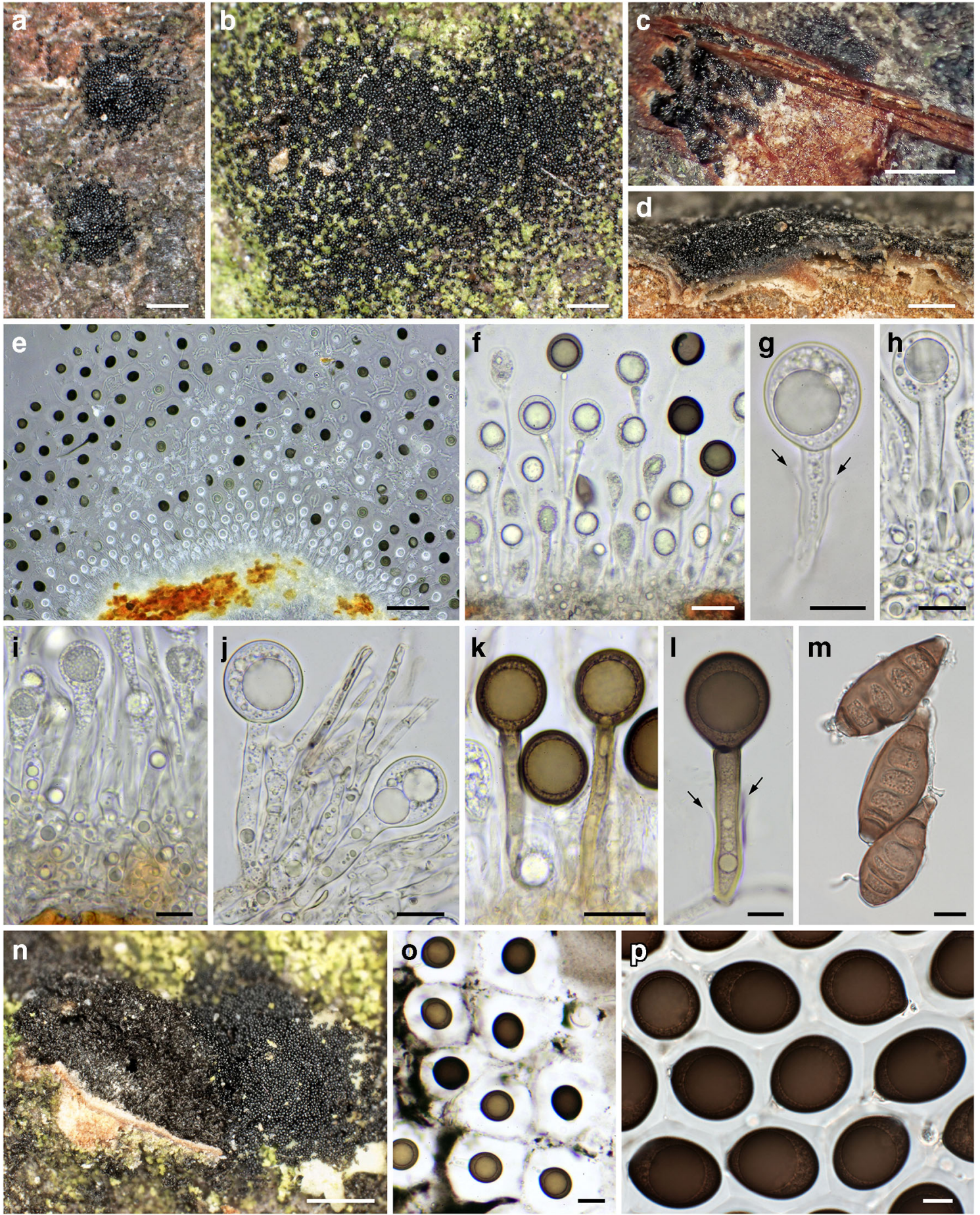

Fig. 6 Mycosphaerangium quercinum, asexual morph ((a, c, e-l, n) WU 40027; (b) WU 40030; (d, o) WU 40031; (m) WU 40032; (p) WU 40028). (a, b) Conidiomata with dispersed, glossy conidia in face view. (c) Conidioma in transverse section, (d, e) Conidioma in vertical section. (f-l) Conidiophores, conidiogenous cells and immature $(\mathbf{f}-\mathbf{j})$ and mature $(\mathbf{k}, \mathbf{l})$ conidia; arrows denoting single annellations of the conidiogenous

verruculose walls that appear smooth in profile view, with a $(2-) 2.5-3.5(-4) \mu \mathrm{m}$ thick $(n=66)$ gelatinous sheath (Fig. 5o) surrounded by a delicate membrane breaking upon maturation or by mechanical pressure, leaving its residues among the cells. (m, n) Conidia (m) and conidioma (n) of Coryneum cf. depressum associated with conidioma of $M$. quercinum. (o, p) Conidia with expanded gelatinous sheaths. All in water; (m) dead, all others vital. Scale bars: (a-d) $200 \mu \mathrm{m}$; (e) $100 \mu \mathrm{m}$; (f) $30 \mu \mathrm{m},(\mathbf{g}-\mathbf{j}, \mathbf{l}, \mathbf{m}, \mathbf{p}) 10 \mu \mathrm{m}$; (k, o) $20 \mu \mathrm{m}$; (n) $500 \mu \mathrm{m}$

mass of swollen sheaths or at the ascus wall (Fig. 5p); sheath expanding around the spores forming longitudinal striae inside the ascus (Fig. 5o, p), widely expanded in released spores (Fig. 5u). 
Asexual morph on the natural substrate: Conidiomata acervular, subperidermal, scattered, scarcely raising the bark, becoming visible in the dry state by black irregular spots of distinctly glossy conidia and sometimes small bumps in the bark after the discharge of the conidia through bark fissures. In the moist state, a gelatinous hyaline mass with small black conidial dots appearing. Conidiomata consisting of a whitish to pale yellowish, compact, more or less pseudoparenchymatous, (17-)19-38(-50)- $\mu \mathrm{m}$-thick base; cells hyaline, septate, elongate, intertwined, thin-walled, (2.5-)3.5-8(-8.7) $\mu \mathrm{m}$ wide, intermingled with some globose cells, containing numerous oil drops, giving rise to the conidiophores. Conidiophores reduced to conidiogenous cells. Conidiogenous cells percurrent, cylindrical, filiform, slightly enlarged apically, (13-)34-117(-225) $\times(2.3-) 4.2-$ $6.8(-9) \mu \mathrm{m}(n=135)$, non-septate, hyaline, turning brown with age; with only a single annellation and conidium on top. Conidia (22.5-)27-34(-41) $\times(20-) 23.5-28(-33) \mu \mathrm{m}$, $1 / \mathrm{w}=(1.0-) 1.1-1.3(-1.5), \mathrm{Me}=30.4 \times 25.8 \mu \mathrm{m}, \mathrm{Qe}=1.18$ $(n=223)$, globose to ellipsoid, with (1.1-)1.2-1.7(-1.8)- $\mu \mathrm{m}$ thick wall, first hyaline, turning brown to nearly black, containing a large globose oil drop (14-)18-21(-23.5)- $\mu \mathrm{m}$ diam $(n=147)$ and numerous small ones, finely verruculose, with a (7-)10.5-18.5(-24.5)- $\mu \mathrm{m}$-thick gelatinous sheath, widely expanded in water.

Culture characteristics: Colonies on CMD 50-mm diam after 3 months at $22^{\circ} \mathrm{C}$, first hyaline, partly or entirely turning brownish or ochre, covered by floccose tufts or a dense white mat of aerial hyphae, with irregular wavy margin; reverse ochraceous with a caramel to dark brown centre. Conidia not observed in culture.

Habitat: on dead corticated branches of Quercus spp., constantly associated with effete conidiomata of Coryneum spp.

Distribution: apparently widely distributed in south-central and Southern Europe; confirmed from eastern Austria, Greece (Crete), Italy and Spain.

Holotype: Spain, Jaén, Fuensanta de Martos, Sierra de la Grana, $37^{\circ} 36^{\prime} 18.93^{\prime \prime} \mathrm{N}, 3^{\circ} 54^{\prime} 55.91^{\prime \prime} \mathrm{W}, 747 \mathrm{~m}$ a.s.1., on dead branch of Quercus faginea, 20 Mar. 2018, leg. S. Tello, S.T.20031801 (WU 40027, holomorph; ex-holotype culture CBS $147011=$ MYT).

Additional specimens examined: Austria, Burgenland, Siegendorf, Siegendorfer Puszta, $47^{\circ} 46^{\prime} 44.2^{\prime \prime}$ N, $16^{\circ} 34^{\prime}$ 53.7" E, on dead corticated branches of Quercus cerris, 25 Apr. 2020, leg. H. Voglmayr and I. Krisai-Greilhuber (WU 40028; asexual morph only); Niederösterreich, Gießhübl, Predigerstuhlwiese, $48^{\circ} 06^{\prime} 28.8^{\prime \prime} \mathrm{N}, 16^{\circ} 12^{\prime} 38.3^{\prime \prime} \mathrm{E}$, on dead corticated branches of Quercus cerris, 28 May 2017, leg. H. Voglmayr (WU 40029; asexual morph only); Hagenbrunn, Bisamberg, near Zigeunerbründl, $48^{\circ} 19^{\prime} 10.6^{\prime \prime} \mathrm{N}, 16^{\circ} 24^{\prime}$ 09.1" E, on dead corticated branches of Quercus cerris, 5 Feb. 2017, leg. H. Voglmayr and W. Jaklitsch (WU 40030; asexual morph only); Wien, Landstraße, Botanical Garden of the University (HBV), $48^{\circ} 11^{\prime} 25.0^{\prime \prime} \mathrm{N}, 16^{\circ} 22^{\prime} 57.6^{\prime \prime} \mathrm{E}$, on dead corticated branches of Quercus cerris, 31 Aug. 2017; ibid., 17 Feb. 2020, leg. H. Voglmayr (WU 40031; asexual morph only); Wien, Hernals, Schwarzenbergpark, northern margin of the Tiefauwiese, $48^{\circ} 14^{\prime} 50.2^{\prime \prime} \mathrm{N}, 16^{\circ} 16^{\prime} 43.3^{\prime \prime} \mathrm{E}$, on dead corticated branches of Quercus cerris, 15 Apr. 2018, leg. H. Voglmayr (WU 40032; asexual morph only); Wien, Ottakring, Wilhelminenberg, Galitzinberg, $48^{\circ} 13^{\prime} 03.9^{\prime \prime} \mathrm{N}$, $16^{\circ} 16^{\prime} 35.8^{\prime \prime}$ E, on dead corticated branches of Quercus cerris, 1 Jul. 2017, leg. H. Voglmayr (WU 40033; asexual morph only). Greece, Crete, Rethimno, Prines, $35^{\circ} 20^{\prime} 15.4^{\prime \prime}$ N, $24^{\circ} 25^{\prime} 14.3^{\prime \prime}$ E, on dead corticated branch of Quercus macrolepis, 7 Jun. 2015, leg. H. Voglmayr and W. Jaklitsch (WU 40034, culture D135 = CBS 144229; asexual morph only); Armeni, $35^{\circ} 17^{\prime} 51.4^{\prime \prime} \mathrm{N}, 24^{\circ} 28^{\prime} 06.6^{\prime \prime} \mathrm{E}$, on dead corticated branch of Quercus macrolepis, 27 Jun. 2018, leg. W. Jaklitsch (WU 40035; asexual morph only). Italy, Sicilia, Etna, above Linguaglossa, $37^{\circ} 50^{\prime} 20.7^{\prime \prime} \mathrm{N}, 15^{\circ} 07^{\prime} 01.0^{\prime \prime} \mathrm{E}$, on dead corticated branch of Quercus pubescens, 18 Jun. 2016, leg. H. Voglmayr and W. Jaklitsch (WU 40036; asexual morph only). Spain, Asturias, Pola de Somiedo, on dead branches of Quercus ilex still attached to the tree, $43^{\circ} 05^{\prime}$ 49.1" N, 6 $6^{\circ} 15^{\prime} 17.3^{\prime \prime} \mathrm{W}, 2$ Jun. 2013, leg. H. Voglmayr (WU 40044); ibid., Camino de Pola a Castro, 43 07' 12.04" $\mathrm{N}, 6^{\circ} 15^{\prime} 15.46^{\prime \prime} \mathrm{W}, 745 \mathrm{~m}$, on dead branches of Quercus ilex still attached to the tree, 8 Jun 2017 , leg. S. Tello S.T.08061701; Jaén, Aldeaquemada, Carretera de Aldeaquemada, 30SVH $6184150351,38^{\circ} 24^{\prime} 02.05^{\prime \prime} \mathrm{N}, 3^{\circ}$ $26^{\prime} 13.23^{\prime \prime}$ W, 975 m, on dead branch of Quercus suber, 23 Feb. 2020, leg. S. Tello S.T.23022002 (WU 40037; asexual morph only); Jaén, Andújar, Peñascales, $38^{\circ} 06^{\prime} 46.58^{\prime \prime} \mathrm{N}, 4^{\circ}$ $01^{\prime} 29.45^{\prime \prime} \mathrm{W}, 650 \mathrm{~m}$, on dead branches of Quercus ilex attached to the tree, in mixed forest of $Q$. ilex and Pinus pinea with Cistus ladanifer, 24 Mar. 2016, leg. S. Tello, (WU 40038, JA-CUSSTA 8291; culture EXT1; holomorph); Jaén, Valdepeñas de Jaén, La Solana, 30SVG 29011 60779, 37 35' $28.82^{\prime \prime} \mathrm{N}, 3^{\circ} 48^{\prime} 14.80^{\prime \prime} \mathrm{W}, 1155 \mathrm{~m}$, on corticated branches of Quercus ilex, 12 May 2016, leg. S. Tello, (JA-CUSSTA 8297, WU 40039; holomorph); Jaén, Valdepeñas de Jaén, Humbría de Ventisqueros, $37^{\circ} 36^{\prime} 47.54^{\prime \prime} \mathrm{N}, 3^{\circ} 44^{\prime} 47.83^{\prime \prime} \mathrm{W}, 1205 \mathrm{~m}$, on dead branches of Quercus ilex still attached to the tree, 13 Aug. 2017, leg. S. Tello S.T.13081703; Jaén, Valdepeñas de Jaén, Puerto de las coberteras, $37^{\circ} 37^{\prime} 19.83^{\prime \prime} \mathrm{N}, 3^{\circ} 45^{\prime} 44.11^{\prime \prime}$ W, $1334 \mathrm{~m}$, on dead branches of Quercus ilex still attached to the tree, 5 Mar. 2017, leg. S. Tello S.T.05031702.

Notes: Mycosphaerangium quercinum resembles the North American M. tetrasporum, which, however, mainly differs by distinctly swollen, clavate, red brown paraphysis tips, lack of croziers at the ascus base and distinctly verruculose ascospore walls. It differs from $M$. magnisporum by distinctly shorter, subglobose to broadly ellipsoid, concolorous ascospores and a different host. In all specimens investigated, conidiomata as well as ascomata of $M$. quercinum are associated with effete 
conidiomata of Coryneum spp., indicating that it is fungicolous. Although M. quercinum seems to be widely distributed in Southern Europe, ascomata are so far only known from Spain.

Mycosphaerangium tetrasporum (Ellis) Verkley, Stud Mycol 44: 156. 1999. Figures 7 and 8.

Basionym. Dermatea tetraspora Ellis, Bull. Torrey bot. Club 6: 108. 1876.

$\equiv$ Cenangium tetrasporum (Ellis) Sacc. Syll. fung. 8: 570. 1889.

$\equiv$ Phaeangium tetrasporum (Ellis) Sacc. \& P. Syd., Syll. fung. 16: 765. 1902.

$\equiv$ Sphaerangium tetrasporum (Ellis) Seaver, North American Cup-fungi, (Inoperculates) (New York): 308. 1951.

Sexual morph: Apothecia 0.4-2-mm diam, erumpent from bark, solitary or in groups of $2-5$, sessile, without a basal stroma, forming circular to irregular plane to concave discs. Receptacle dark red-brown and scaly and the raised margin slightly paler. Hymenium roughened, dark brown to black. Ectal excipulum consisting of a 50-100- $\mu \mathrm{m}$-thick layer, narrower at the margin, of dark orange brown textura globulosa-angularis, cells (9-)13-23(-28)- $\mu \mathrm{m}$ diam, with walls $1-2 \mu \mathrm{m}$ thick. Medullary excipulum consisting of orange brown textura globulosa-angularis, cells (7-)13-24($33)-\mu \mathrm{m}$ diam. Subhymenium made of hyaline to pale brown textura intricata of densely interwoven thin-walled hyphae. Paraphyses ca. 250-310 $\mu \mathrm{m}$ long, 2.5-4.8 $\mu \mathrm{m}$ wide, cylindrical, hyaline, septate, branched, longer than the asci, with swollen, club-shaped red brown tips 5-11 $\mu \mathrm{m}$ wide, not encrusted. Asci 185-265(-305) × (26-)29-38(-42) $\mu \mathrm{m}(n=29)$, cylindrical-clavate, unitunicate, with rounded to subtruncate apex, inamyloid, without visible apical apparatus, containing 4 uniseriately arranged ascospores, base tapering, with simple septum. Ascus dehiscence unknown. Ascospores (23.5-)26.5$31.5(-34) \times(18.5-) 23-27(-29) \mu \mathrm{m}, 1 / \mathrm{w}=(1.0-) 1.1-1.2(-$ $1.4), \mathrm{Me}=29 \times 25 \mu \mathrm{m}, \mathrm{Qe}=1.15(n=88)$, globose to ellipsoid, first hyaline, turning pale brown and finally dark brown to nearly black when mature, containing a large globose oil drop, walls verruculose and appearing rough in profile view, with a prominent refractive gelatinous sheath widely expanding in released spores.

Asexual morph: Conidiomata acervular, subperidermal, scattered, scarcely raising the bark and becoming visible in the dry state by black irregular spots of distinctly glossy conidia and sometimes small bumps in the bark after the discharge of the conidia through bark fissures. Conidiophores arising from conidiomatal base, reduced to conidiogenous cells. Conidiogenous cells percurrent, cylindrical, filiform, slightly enlarged apically, 30-100 × (6-)6.3-8.3(-9.5) $\mu \mathrm{m}$, non-septate, hyaline, turning brownish with age; with only a single annellation and conidium on top. Conidia (22.5-)26$33(-35.5) \times(20.5-) 22.5-30.5(-33) \mu \mathrm{m}, 1 / \mathrm{w}=(1.0-) 1.1-$
1.2(-1.3), $\mathrm{Me}=29.5 \times 26.5 \mu \mathrm{m}, \mathrm{Qe}=1.13(n=55)$, globose to broadly ellipsoid, brown to nearly black, finely verruculose, surrounded by a gelatinous sheath widely expanding in water.

Habitat: on dead corticated branches of Quercus spp. (Q. coccinea, $Q$. rubra), constantly associated with effete conidiomata or stromata of Coryneum spp.

Distribution: Eastern North America (USA, Canada).

Typification: USA, NJ, Newfield, on dead limbs of Quercus coccinea still attached to the tree, March (without day and year), J.B. Ellis s.n., distributed in Ellis. N. Am. Fungi 70 (GZU 000335639, lectotype here designated; MBT393681; isotype GZU 000335720; holomorph).

Additional specimens examined: Canada, Québec, Montérégie, on dead corticated branches of Quercus rubra, Apr. 2014, A. Lavoie (WU 40040).

Notes: Mycosphaerangium tetrasporum resembles the European M. quercinum, which, however, differs by irregularly sinuous-knobby hyaline paraphysis tips encrusted by amorphous brown plaques, the presence of croziers at the ascus base, and by finely verruculose spores appearing smooth in profile view. It differs from M. magnisporum by distinctly shorter, subglobose to broadly ellipsoid, concolorous ascospores and a different host. In all specimens investigated, conidiomata as well as ascomata of M. tetrasporum are associated with effete conidiomata or stromata of Coryneum species. To our knowledge, besides the type specimen from Newfield, NY (USA), only a recent Canadian collection is known (see above), which unfortunately is scant and in poor condition, and therefore no DNA data could be generated.

Neomelanconium Petr., Annls mycol. 38(2-4): 208. 1940, emend. Voglmayr.

Type species: Neomelanconium gelatosporum (H. Zimm.) Petr.

Sexual morph apothecial, circular to polyangular, erumpent through bark, concave to plane, solitary or in groups, sessile, rough, disk black, basal stroma absent. Receptacle whitish, pulverulent, with an external layer of crystals, with incurved, inversely stellate marginal teeth. Paraphyses embedded in hymenial gel, slightly longer than the asci, filiform, hyaline, septate, simple or branched, sometimes anastomosing, with hyaline to brownish slightly swollen tips. Asci cylindrical-clavate, thin-walled, unitunicate, with broadly rounded apex without a distinct apical apparatus, with 8 uniseriately arranged ascospores. Ascospores dark brown, aseptate, subglobose to ellipsoid, with a thick, dark brown, minutely warted wall, surrounded by a prominent hyaline gelatinous sheath.

Asexual morph acervular, often conspicuous due to black, glossy, effused conidial masses. Conidiomata subperidermal, not to slightly elevating the bark, solitary, scattered, lenticular, with thin, whitish pseudoparenchymatous base, exuding conidia in a black mucoid droplets. Conidiophores emerging 

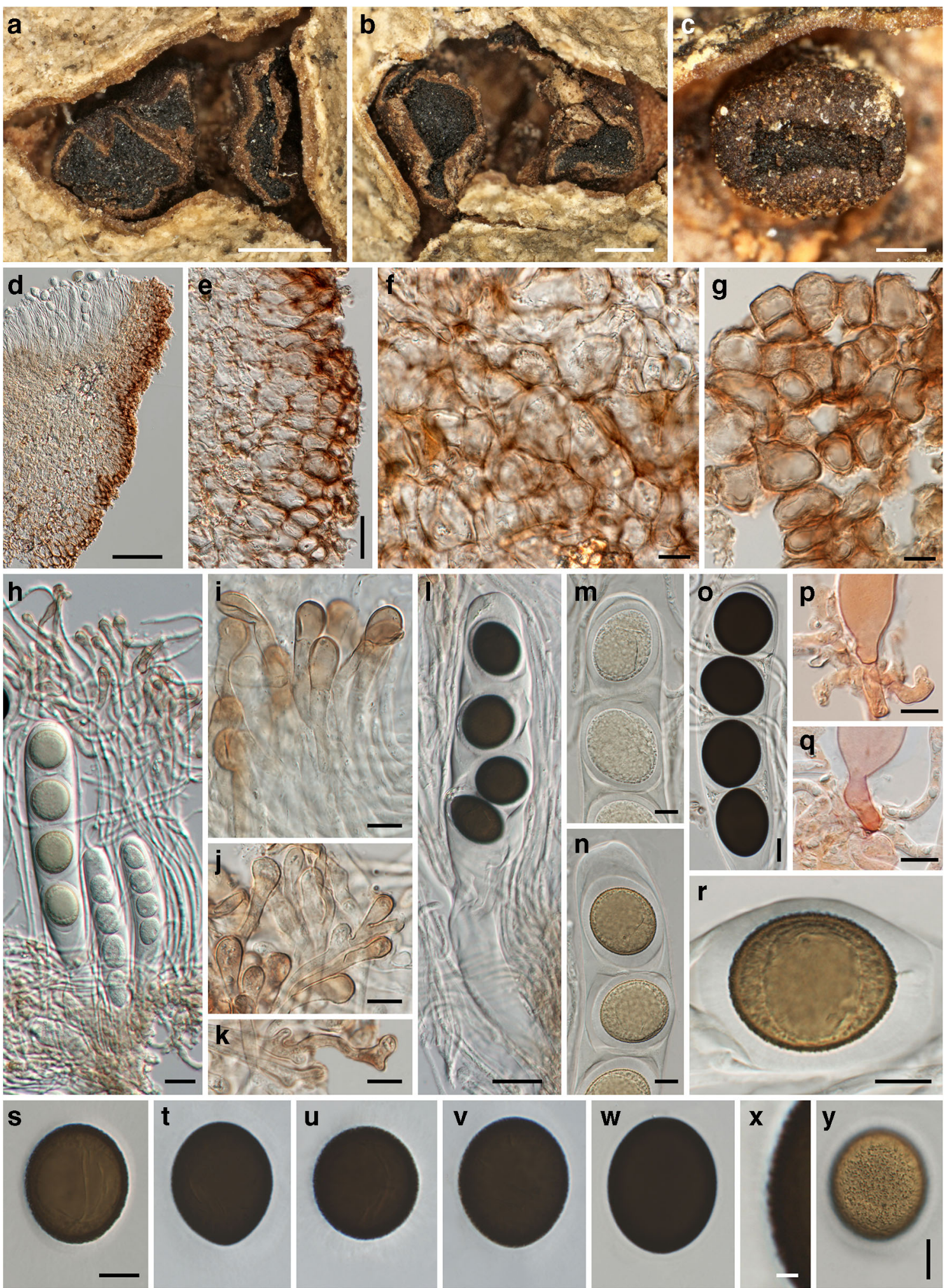

Fig. 7 Mycosphaerangium tetrasporum, sexual morph $((\mathbf{a}-\mathbf{c}, \mathbf{g}, \mathbf{i}, \mathbf{l}-\mathbf{0}, \mathbf{q}-$ u, w, x) GZU 000335639, lectotype; (d-f, h, j, k, p, v) WU 40040). (a-c) Apothecia in face view. (d) Apothecium margin in section. (e) Marginal excipulum in section. (f) Medulla in section. (g) Ectal excipulum cells in squash mount. (h) Paraphyses and immature asci. (i-k) Swollen, reddish brown paraphysis tips. (l) Mature ascus with four ascospores surrounded

by thick gelatinous sheaths. (m-0) Ascus apices $((\mathbf{m}, \mathbf{n})$ immature). $(\mathbf{p}, \mathbf{q})$ Ascus bases with simple septa. (r-w) Ascospores (in (r) showing widely expanded gelatinous sheath and distinctly verruculose wall; $(\mathbf{x}, \mathbf{y})$ verruculose contours and wall in face view). All mounts dead and in $3 \% \mathrm{KOH}$, except $(\mathbf{p}, \mathbf{q})$ in Congo red. Scale bars: $(\mathbf{a}, \mathbf{b}) 500 \mu \mathrm{m} ;(\mathbf{c}, \mathbf{d})$ $200 \mu \mathrm{m}$; (e) $30 \mu \mathrm{m}$; (f-k, m-w, y) $10 \mu \mathrm{m}$; (l) $20 \mu \mathrm{m}$; (x) $2 \mu \mathrm{m}$ 

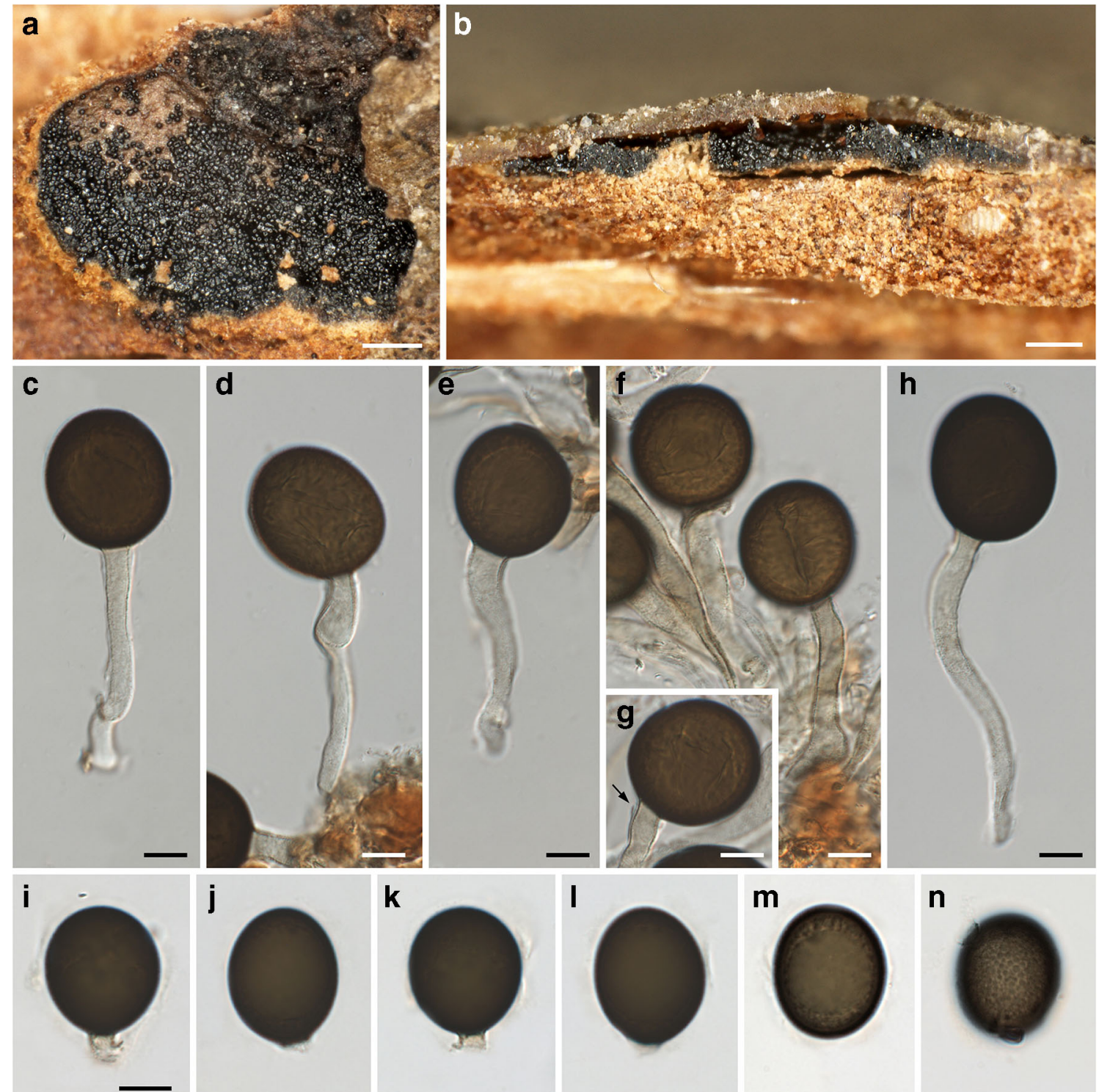
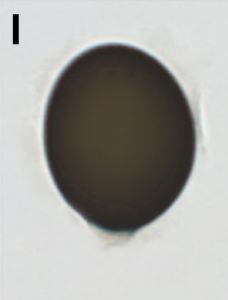

m

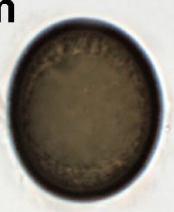

n

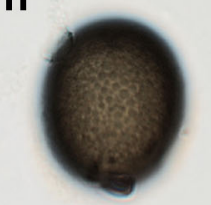

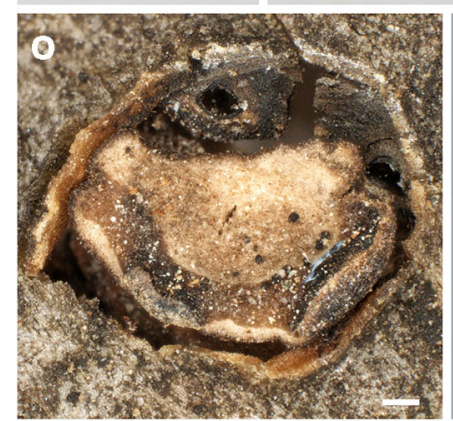
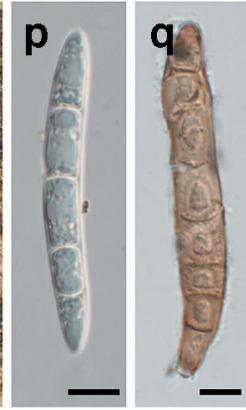

Fig. 8 Mycosphaerangium tetrasporum, asexual morph ((a-h) GZU 000335720, isotype; (i-q) Lavoie; (r-u) GZU 000335639, lectotype). (a) Conidiomata in face view after removal of cortical layer. (b) Conidioma in vertical section. $(\mathbf{c}-\mathbf{h})$ Mature conidia on conidiogenous cells; arrow denoting single annellation. (i-n) Conidia ((m) showing large

from a more or less pseudoparenchymatous base, reduced to the conidiogenous cells, hyaline, smooth, cylindrical. Conidiogenous cells percurrent, hyaline, usually with a single,
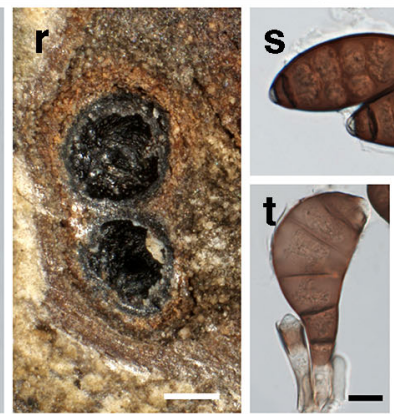

oil drop, (n) verrucae on inner wall). (o-u) Stromata $(\mathbf{o}, \mathbf{r})$, ascospores (p, $\mathbf{s})$ and conidia $(\mathbf{q}, \mathbf{t}, \mathbf{u})$ of Coryneum spp. associated with $M$. tetrasporum. All mounts in 3\% KOH and dead. Scale bars: (a, b, o, r) $200 \mu \mathrm{m}$; (c-n, p, q, s-u) $10 \mu \mathrm{m}$

rarely few, annellations. Conidia dark brown, aseptate, globose, ellipsoid, ovoid, pyriform to clavate, apex broadly rounded, base truncate, thick-walled, guttulate, usually with 
a large and numerous small guttules, with finely verruculose wall, surrounded by a prominent hyaline gelatinous sheath expanding in water.

Notes: No sexual morph has been known for Neomelanconium until this study, and the connection with the mycosphaerangium-like sexual morph is confirmed by morphological data. Neomelanconium differs from the closely related Mycosphaerangium mainly by eight-spored asci and marginal, inversely stellate excipular teeth with a textura prismatica-porrecta covered by an external layer of white crystals. In addition, unlike in Mycosphaerangium, there is no evidence for association with fungi in Neomelanconium.

Morphology of the second species, $N$. deightonii, fits the generic type, and it is therefore retained within the genus, albeit no sequence data are available to verify its phylogenetic affiliation with Neomelanconium. Based on the lack of a gel sheath around the conidia, Crous et al. (2019) transferred the third species of the genus, N. spartii, to Pseudomelanconium.

Neomelanconium deightonii Petr., Sydowia 8(1-6): 51. 1954. Figure 9.

Sexual morph: not known.

Asexual morph: Conidiomata acervular, plurilocular, subperidermal, scattered, raising the bark, at maturity covered by conspicuous black, irregular spots of glossy conidia. Conidiophores arising from a brown conidiomatal base, reduced to conidiogenous cells. Conidiogenous cells percurrent, cylindrical to ampulliform, (16-)19-28(38) $\mu \mathrm{m} \times(4.7-) 5.5-8(-9.5) \mu \mathrm{m}(n=30)$, non-septate, hyaline, at base turning brownish with age, smooth; with 1(-3) annellations and a single conidium on top. Conidia $(18.5-) 18.7-20.5(-22.2) \times(17-) 18-19.3(-20) \mu \mathrm{m}$, $1 / \mathrm{w}=(1-) 1-1.1(-1.3), \mathrm{Me}=19.7 \times 18.6 \mu \mathrm{m}, \mathrm{Qe}=1.06(\mathrm{n}=$ 30 ), globose to ellipsoid, dark brown, surrounded by a gelatinous sheath rapidly dissolving in water.

Habitat: on dead corticated branches of Spondias mombin (Anacardiaceae).

Distribution: known only from the type locality in Sierra Leone (Africa).

Typification: Sierra Leone, Njala Kori, in bark of dead branches of Spondias mombin, 28 Jan. 1953, F.C. Deighton M 8099 (W 0102726, lectotype here designated; MBT393682; isotypes W 0102724, W 0102725).

Notes: The conidiomata, conidiogenous cells and conidia of Neomelanconium deightonii resemble those of the generic type, $N$. gelatosporum. As already mentioned by Petrak (1954), $N$. deightonii differs from $N$. gelatosporum mainly by irregularly plurilocular conidiomata, which led him to propose the subgenus Neomelanconiopsis for it. Although no sequence data are available, for the time being, we decide to maintain $N$. deightonii within Neomelanconium based on morphological resemblance.
There is some confusion in the literature about the gel sheath surrounding the conidia. While Petrak (1954) described a rapidly dissolving gel sheath $1.5-2.5 \mu \mathrm{m}$ wide, Sutton (1980) reported the absence of a gelatinous sheath. Re-investigations of the original collections showed that within conidiomata, the conidia were embedded in an extensive amorphous gel matrix (Fig. 9h) that apparently originated from dissolved conidial gel sheaths, as remnants were seen on some conidiophores (Fig. 9j). With the evidence at hand, we consider Petrak's (1954) observations to be correct; a gel sheath surrounding the conidia may be only observed in fresh material, becoming confluent and agglutinated to an amorphous matrix after prolonged storage.

Three isotype collections are present in $\mathrm{W}$, of which $\mathrm{W}$ 0102726 is here selected as lectotype based on abundance.

Neomelanconium gelatosporum (H. Zimm.) Petr., Annls mycol. 38(2-4): 209. 1940. Figures 10, 11 and 12.

Basionym. Melanconium gelatosporum H. Zimm., Verh. nat. Ver. Brünn 52: 111. 1914.

= Sphaerangium tiliae Seaver, North American Cup-fungi, (Inoperculates) (New York): 309. 1951.

$\equiv$ Mycosphaerangium tiliae (Seaver) Verkley, Stud. Mycol. 44: 157. 1999.

Sexual morph: Apothecia 0.5-1.2(-2)-mm diam $(n=27)$, erumpent from bark, solitary, sessile, without a basal stroma, broadly adnate to the substrate, first closed, then opening with more or less irregular, inversely stellate whitish teeth 200 $440 \mu \mathrm{m}$ long and $170-800 \mu \mathrm{m}$ broad, exposing the circular to polyangular, plane, blackish hymenium. Receptacle and margin coated by whitish, pulverulent amorphous crystals. Ectal excipulum red-brown, consisting of a ca. forty- to $100-\mu \mathrm{m}$-thick layer, towards apothecium base of a textura globulosa-angularis of thin-walled cells $12-23 \times 6-11 \mu \mathrm{m}$, at margin teeth with a textura prismatica-porrecta of concolorous, thin-walled cells $10-25(-34) \times 3-8 \mu \mathrm{m}$, teeth cells close to the hymenium hyaline, elongate, apically rounded 4-8 $\mu \mathrm{m}$ wide. Medullary excipulum consisting of reddish to light brown textura angularis of thin-walled cells (8-)13$31(-40) \times(6.5-) 8.5-15(-19.5) \mu \mathrm{m}$. Subhymenium made of subhyaline to brownish textura angularis of thin-walled cells 7-16- $\mu \mathrm{m}$ diam. Paraphyses ca. 270-330 $\mu \mathrm{m}$ long, 2-3 $\mu \mathrm{m}$ wide, cylindrical, hyaline, septate, branched, longer than the asci, with slightly swollen, club-shaped tips 3-6 $\mu \mathrm{m}$ wide, not encrusted but embedded in a brownish, granular, gelatinous matrix. Asci (250-)260-300(-310) × (23-)23.5-26.5(27.5) $\mu \mathrm{m}(n=10)$, cylindrical, unitunicate, with rounded apex, inamyloid, without visible apical apparatus, containing 8 uniseriately arranged ascospores, base abruptly tapering, with simple septum. Ascus dehiscence unknown. Ascospores $(18-) 22-26(-27) \times(15-) 16.5-18.5(-19.5) \mu \mathrm{m}$, $\mathrm{l} / \mathrm{w}=(1.2-) 1.3-1.5(-1.7), \mathrm{Me}=24.1 \times 17.5 \mu \mathrm{m}, \mathrm{Qe}=1.38$ $(n=66)$, ellipsoid, multiguttulate, first hyaline, turning pale 

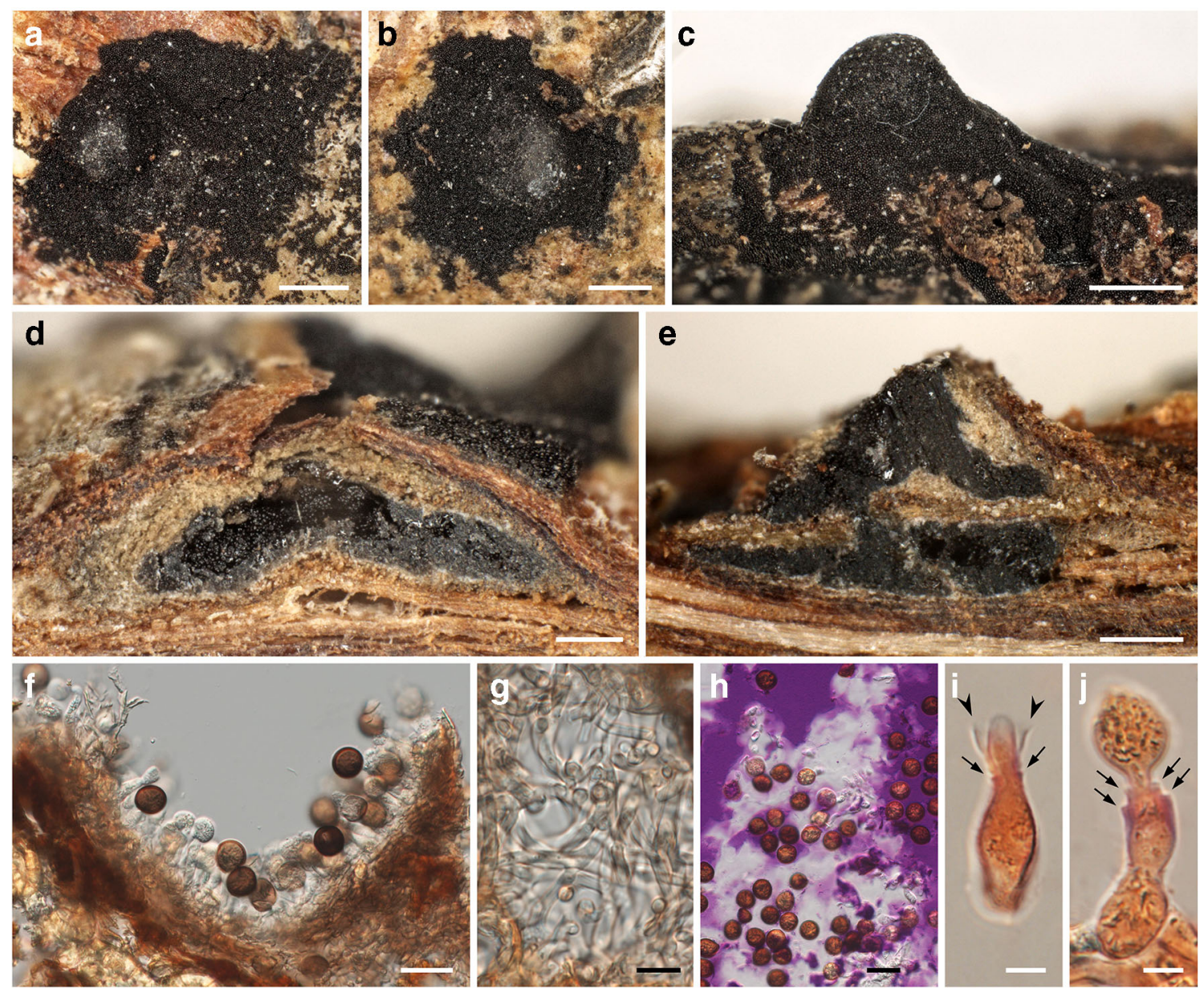
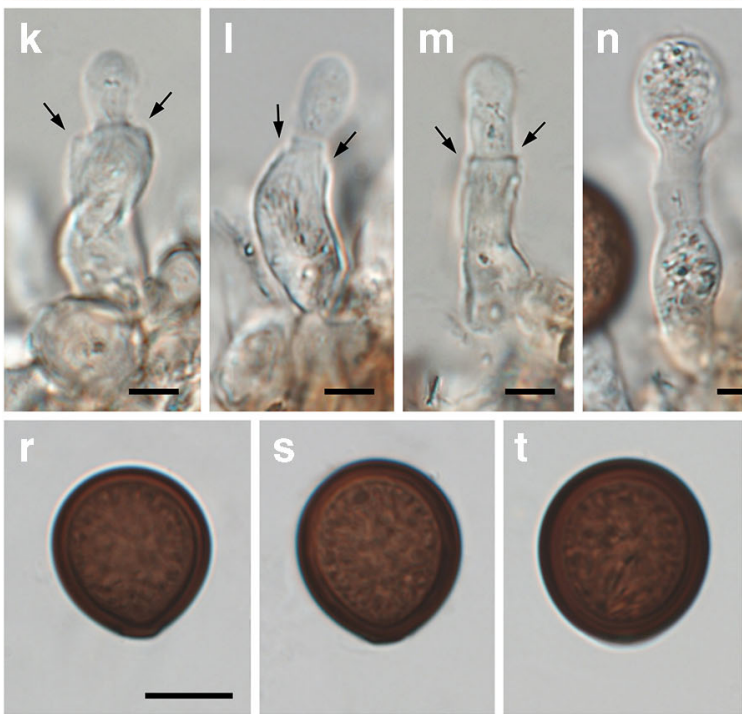

Fig. 9 Neomelanconium deightonii, asexual morph ((a-d) W 0102726, lectotype; (e-w) W 0102724, isotype). (a, b) Conidiomata with dispersed, glossy conidia in face view. (c) Conidioma in lateral view. (d-f) Conidiomata in vertical section. (g) Hyphae of conidiomatal base. (h) Conidia in Indian ink showing the gelatinous matrix. (i-q) Immature
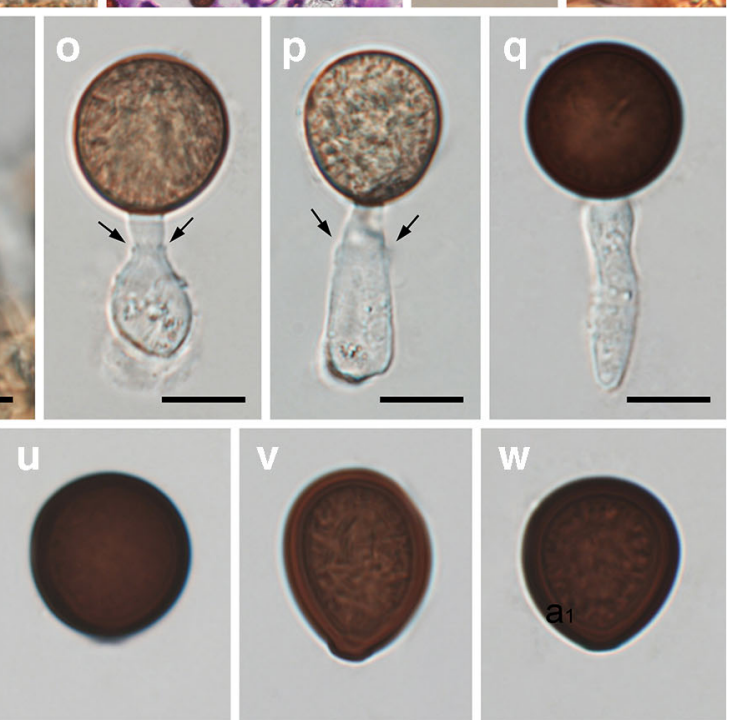

(i-p) and mature (q) conidia on conidiogenous cells; arrows and arrowheads denoting annellations and remnants of gelatinous sheath of conidium, respectively. (r-w) Conidia. All mounts dead and in 3\% KOH, except (h) in Indian ink and (i, j) in Congo red. Scale bars: (a-c) $500 \mu \mathrm{m}$; (d, e) $200 \mu \mathrm{m}$; (f, h) $30 \mu \mathrm{m}$; (g, o-w) $10 \mu \mathrm{m}$; (i-n) $5 \mu \mathrm{m}$

in profile view, with a prominent refractive gelatinous sheath widely expanded in released spores. brown and finally dark brown to nearly black when mature, wall finely verruculose appearing smooth to finely roughend 

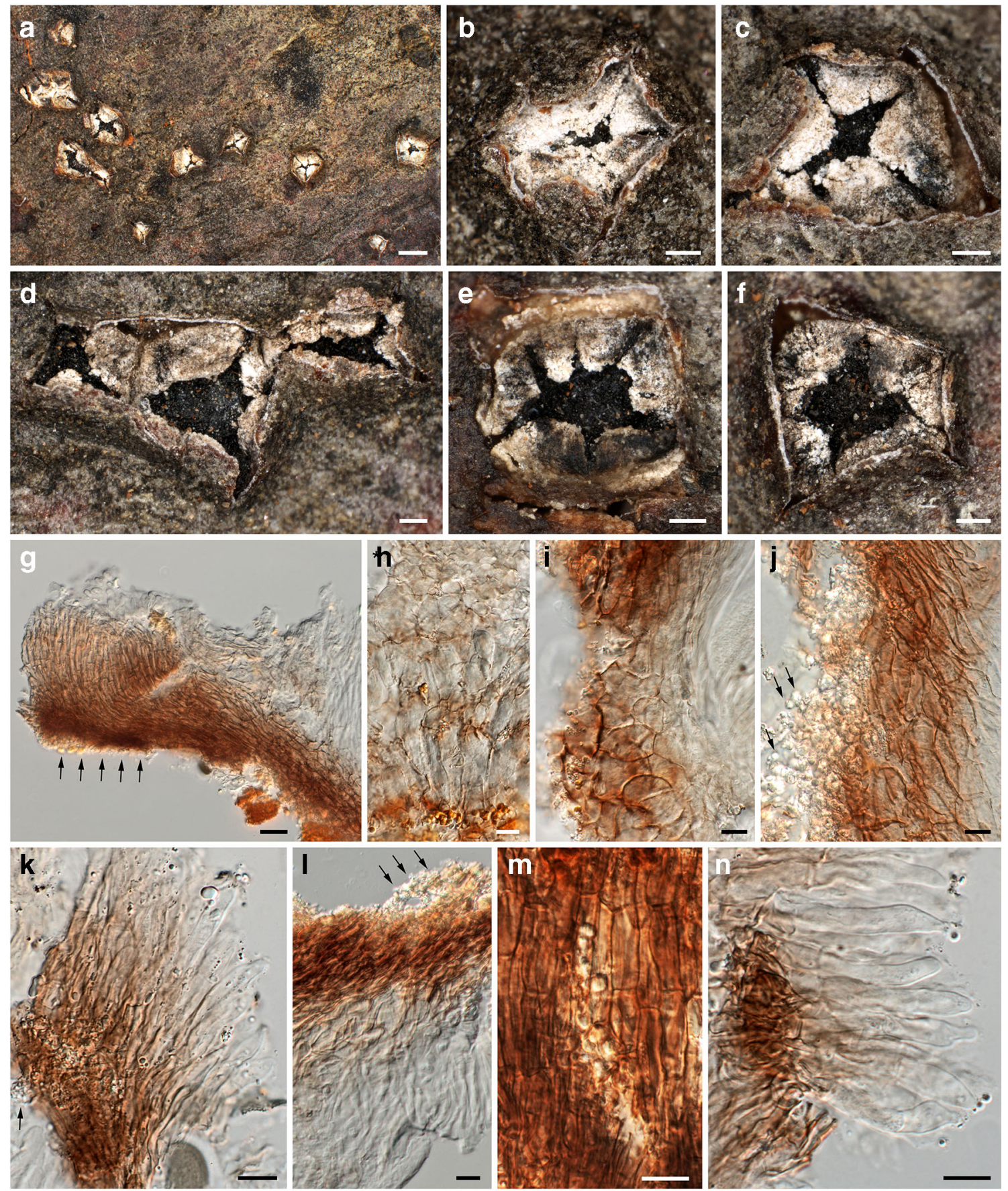

Fig. 10 Neomelanconium gelatosporum, sexual morph (NY 02792207, lectotype of Sphaerangium tiliae). (a-f) Apothecia in face view. (g) Ectal excipulum and excipulum teeth in section; arrows denoting external crystals. (h) Medullary excipulum and subhymenium in section. (i) Ectal excipulum in section at base. (j-l) Excipulum teeth in section;

Asexual morph: Conidiomata acervular, subperidermal, lenticular, scattered, scarcely raising the bark and becoming visible in the dry state by black irregular spots of distinctly glossy conidia and sometimes distinct bumps in the bark after the discharge of the conidia through bark fissures. Conidiophores arising from a white to cream conidiomatal arrows denoting external crystals. (m) Excipulum teeth in squash mount, showing textura prismatica-porrecta. (n) Hyaline, elongate, apically rounded end cells of excipulum teeth. All mounts in $3 \% \mathrm{KOH}$ and dead. Scale bars: (a) $1 \mathrm{~mm}$; (b-f) $200 \mu \mathrm{m}$; (g) $20 \mu \mathrm{m}$; (h-n) $10 \mu \mathrm{m}$

base, reduced to conidiogenous cells. Conidiogenous cells percurrent, cylindrical to ampulliform, (18.7-)21.5-30(34.5) $\mu \mathrm{m} \times(6.2-) 7.7-10(-11) \mu \mathrm{m}(n=42)$, non-septate, hyaline, at base turning brownish with age, smooth; with usually a single annellation and conidium on top. Conidia (21.5-)24.5-28(-32.5) ×(14-)17-19.5(-21) $\mu \mathrm{m}$, 

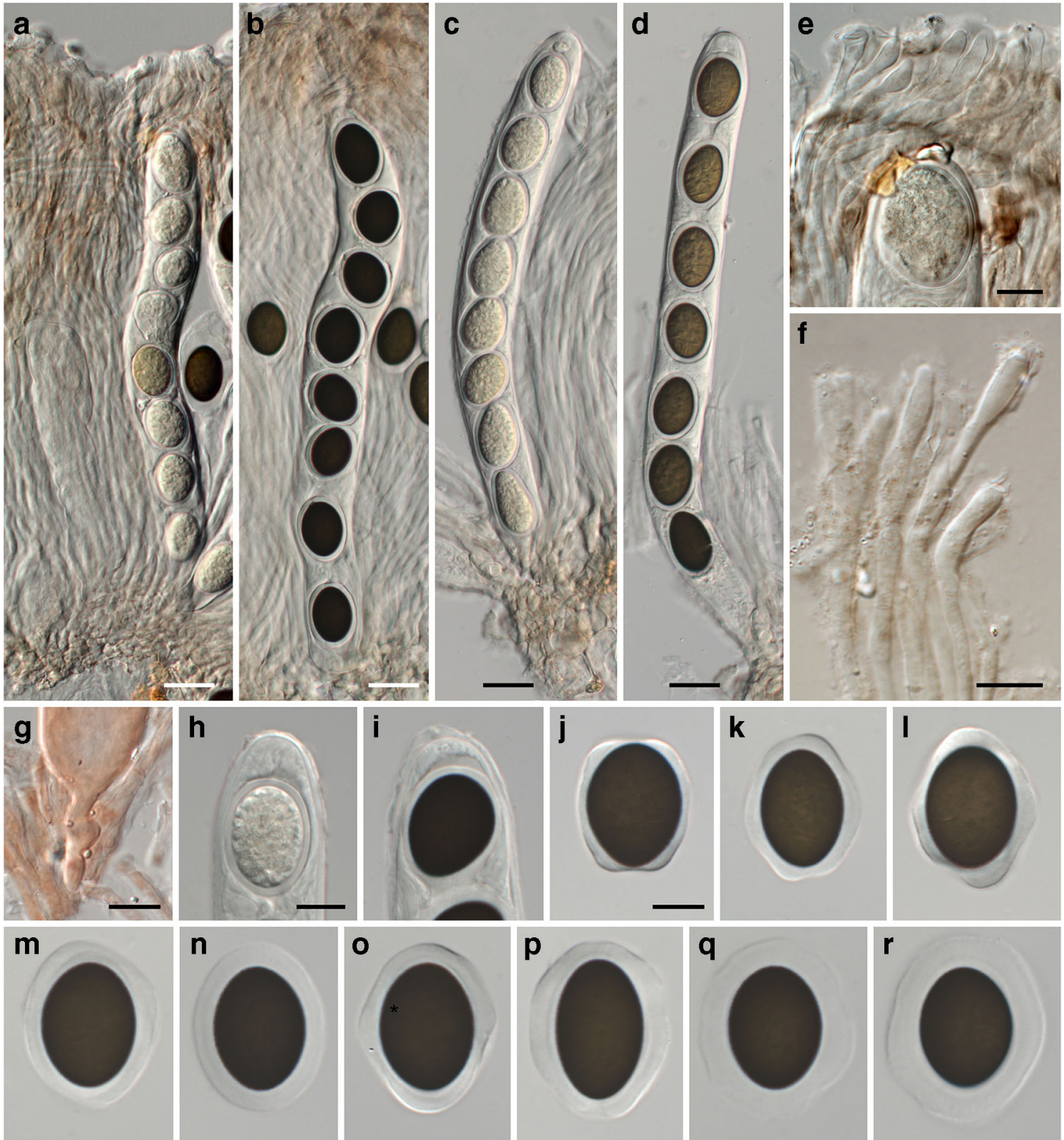

Fig. 11 Neomelanconium gelatosporum, sexual morph (NY 02792207, lectotype of Sphaerangium tiliae). (a-d) Asci $((\mathbf{a}, \mathbf{c})$ immature, $(\mathbf{b}, \mathbf{d})$ mature) and paraphyses. (e, f) Apically swollen paraphysis tips embedded in pale brownish gelatinous matrix and ascus apex (e). (g)

Ascus base with simple septum. (h, i) Ascus apices ((h) immature, (i) mature). (j-r) Ascospores. All in $3 \% \mathrm{KOH}$ and dead. Scale bars: (a-d) $20 \mu \mathrm{m},(\mathbf{e}-\mathbf{r}) 10 \mu \mathrm{m}$

$\mathrm{l} / \mathrm{w}=(1.2-) 1.3-1.6(-2), \mathrm{Me}=26.3 \times 18.2 \mu \mathrm{m}, \mathrm{Qe}=1.45$ $(n=260)$, globose to ellipsoid, olive brown to nearly black, containing a large globose oil drop and numerous small guttules, with finely verruculose wall surrounded by a gelatinous sheath widely expanding in water.

Culture characteristics: Colonies on CMD 45-mm diam after 2 months at $22{ }^{\circ} \mathrm{C}$, first cream, becoming yellowish with brownish spots in the centre, surface shining, without aerial hyphae, with regular margin; reverse yellow with a darker centre. Conidia not observed in culture.

Habitat: on dead corticated branches of Tilia spp.

Distribution: Europe (known from Austria, Czech Republic, Germany) and North America (eastern USA).

Typification: Czech Republic, Morava, Lednice (formerly Eisgrub), Unterwald, on dead stems and branches of Tilia sp., 15 Jan. 1913, H. Zimmermann (W 1978-11035, isotype of Melanconium gelatosporum). USA, GA, Clarke, Athens, University of Georgia, Agricultural Campus, in bark of Tilia americana var. heterophylla, 15 Feb. 1934, J.H. Miller (NY 02792207, lectotype of Sphaerangium tiliae here designated; MBT393939; isotype GAM00009299; holomorph). 


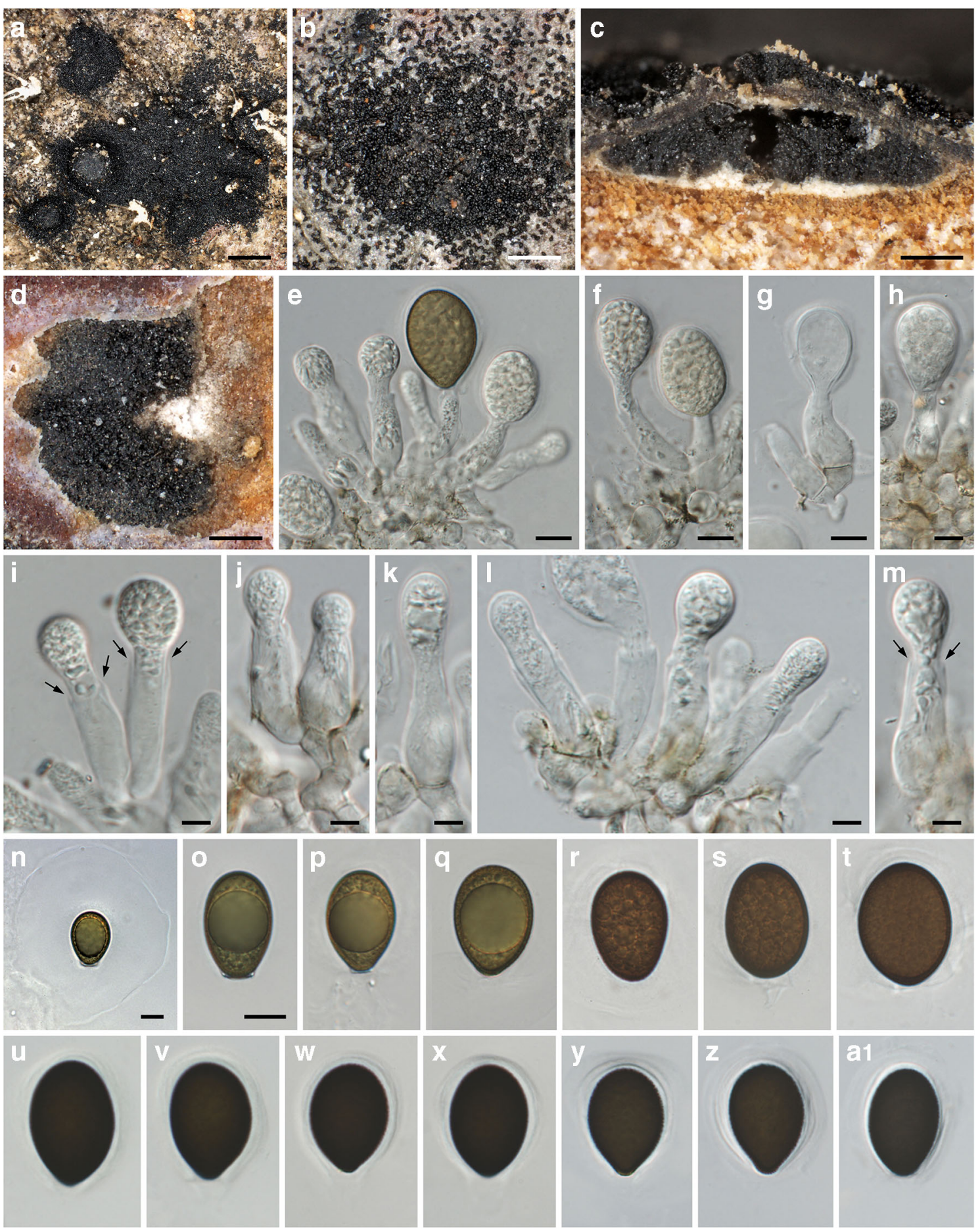

Fig. 12 Neomelanconium gelatosporum, asexual morph $((\mathbf{a}, \mathbf{c}-\mathbf{f}, \mathbf{i}, \mathbf{u}-\mathbf{x})$ W 1978-11035, isotype of Melanconium gelatosporum; (b, $\mathbf{g}, \mathbf{h}, \mathbf{j}-\mathbf{m}, \mathbf{y}-$ a1) NY 02792207, lectotype of Sphaerangium tiliae; (n-q) WU 40042; (r-t) WU 40041). (a, b) Conidiomata with dispersed, glossy conidia in face view. (c) Conidioma in vertical section. (d) Conidioma in transverse section. (e-m) Immature (e-m) and partly mature (e) conidia on conidiogenous cells; arrows denoting single annellations. (n-a1) Conidia ((n) with widely expanded gelatinous sheath). All in water; (nt) vital, all others dead. Scale bars: (a) $500 \mathrm{~mm}$; (b-d) $200 \mu \mathrm{m}$; (e-g, na1) $10 \mu \mathrm{m},(\mathbf{h}-\mathbf{m}) 5 \mu \mathrm{m}$
Additional specimens examined: Austria, Niederösterreich, Mayerling, Helenental, $48^{\circ} 02^{\prime} 15.2^{\prime \prime} \mathrm{N}, 16^{\circ} 06^{\prime} 33.8^{\prime \prime} \mathrm{E}$, on corticated fallen branches of Tilia sp., 8 Dec. 2016, H. Voglmayr (WU 40041; culture NG = CBS 143625);
Oberösterreich, Raab, Wetzlbach, $48^{\circ} 21^{\prime} 28.7^{\prime \prime} \mathrm{N}, 13^{\circ} 40^{\prime}$ 15.7" E, on corticated fallen branches of Tilia cordata, 28 Dec. 2016, H. Voglmayr (WU 40042; culture NG1 = CBS 143626); St. Willibald, Große Sallet, riverine forest SE 
Loitzmayr, $48^{\circ} 20^{\prime} 42.9^{\prime \prime} \mathrm{N}, 13^{\circ} 42^{\prime} 59.6^{\prime \prime} \mathrm{E}$, on corticated fallen branches of Tilia cordata, 12 Apr. 2020, H. Voglmayr (WU 40043). USA, GA, Clarke, Athens, University of Georgia, Agricultural Campus, in bark of Tilia americana var. heterophylla, 17 Dec. 1940, G.E. Thompson and J.H. Miller (GAM 00010426, holomorph).

Notes: Neomelanconium gelatosporum has been described as asexual morph from Europe, and no sexual morph is yet known from Europe. The type specimen of the North American Mycosphaerangium tiliae, here considered to be a synonym of $N$. gelatosporum, contains the holomorph. No sequence data are available for $M$. tiliae, but its asexual morph tightly associated with apothecia is morphologically indistinguishable from the European $N$. gelatosporum, indicating conspecificity of the European and North American collections.

Crous et al. (2019) lectotypified the species with a copy of the exsiccatum preserved in $\mathrm{H}$, which they epitypified with a recent collection from Germany for which sequences were generated. Our sequences are identical with those of Crous et al. (2019), and we here add an emended description based on own observations of sexual and asexual morphs, complemented with published descriptions. Conversely to Crous et al. (2019) who observed macro- and microconidia in pure culture, no asexual morph was formed in our cultures.

The original description of Sphaerangium tiliae by Seaver (1941) is fragmentary, as it is mostly confined to macroscopic observations. Apart from paraphyses, asci and ascospores, no microscopic data were provided for important apothecial features like excipulum and subhymenium. Although the lectotype collection of Mycosphaerangium tiliae is abundant, the investigations were hampered by the very brittle apothecia which precluded preparing entire apothecial sections, and therefore microscopic investigations were kept to a minimum to preserve the type. Thus, only section fragments and squash mounts could be microscopically observed and illustrated, especially for the very delicate excipulum teeth.

\section{Discussion}

Until our investigations, the phylogenetic affiliation of the genus Mycosphaerangium within Helotiales remained unclear, and no asexual morph was known. Based on our morphological and molecular phylogenetic data, a close relationship of the genera Mycosphaerangium and Neomelanconium is here conclusively established. This is in line with morphological similarities of their sexual and asexual morphs, as both ascospores and conidia have a similar size, shape, colour and, most conspicuously, a prominent, widely expanding gel sheath. However, the genus Neomelanconium, for which a connection with a sexual morph is here provided for the first time, differs from Mycosphaerangium in several respects (e.g. 8-spored asci, inversely stellate, white excipulum teeth with a different tissue type). Therefore, the genera Mycosphaerangium and Neomelanconium are here recognized as distinct albeit closely related genera. Although no sequence data are yet available for the North American M. tetrasporum and M. magnisporum, their morphology and ecology leave no doubts that they are closely related to the new European species $M$. quercinum, for which molecular data of both morphs are available.

Also ecologically, there are differences between the genera Mycosphaerangium and Neomelanconium. For the first time, we here report a close, regular association of all Mycosphaerangium species with effete fructifications of the diaporthalean genus Coryneum, indicating a fungicolous habit of Mycosphaerangium. However, it is currently unclear whether this relation with Coryneum is parasitic or necrotrophic. No such association with other fungi was evident in Neomelanconium species, which appear to be saprotrophic on their host plants.

Remarkably, no sexual morph has been found for Neomelanconium gelatosporum in Europe. However, this may be due to climatic reasons; likewise, also for the newly described $M$. quercinum, no sexual morph is known from Central European accessions despite thorough searches for several years, while it has been repeatedly found in Spain. Therefore, it may be worth searching for the sexual morph of $N$. gelatosporum in warmer, more southern latitudes.

As pointed out by Pärtel and Põldmaa (2019), the Cenangiaceae are a morphologically diverse and heterogeneous assemblage, both in their sexual and asexual morphs. With the inclusion of Hemiphacidiaceae, the extended Cenangiaceae contains members with various ascomatal morphology, ranging from hemiphacidioid, reduced apothecia submerged in the substrate to erumpent, cenangioid, cupulate, rarely even capitate, apothecia (Pärtel et al. 2017). While shape and size of the ascomata is variable between genera, most representatives share apothecia which are closed in young stages or in dry periods, either by a lid or a roof-like apothecial margin (Pärtel et al. 2017). In micromorphology, representatives are typically characterized by Calycina-like, usually amyloid apical ascus rings, hyaline (rarely brown) unicellular ascospores and frequent occurrenc of refractive vacuolar bodies (VBs) in the paraphyses or the excipular cells (Jaklitsch et al. 2016, Pärtel et al. 2017).

Asexual morphs in Cenangiaceae are poorly known and documented (Pärtel and Põldmaa 2019). Where known, they are morphologically diverse, being acervular, sporodochial or stromatic with various conidial types, ranging from multicellular stauroconidia to peanut-shaped, allantoid or cylindrical, unicellular conidia with or without appendages (Pärtel et al. 2017, Pärtel and Põldmaa 2019). However, acropleurogenous conidiogeneous cells with conidia developing apically and along the sides were considered to be a common character for Cenangiaceae (Pärtel and Põldmaa 2019). 
By their dark brown verruculose ascospores and conidia surrounded by a massive gel sheath, the lack of a visible apical apparatus and, at least in M. quercinum, of vacuolar bodies (VBs), the genera Mycosphaerangium and Neomelanconium deviate significantly from other Cenangiaceae, widening its morphological diversity. Based on the deviating ascal and ascospore features, Verkley (1999) even speculated about a closer affinity of Mycosphaerangium with Pezizales, but he could not determine the dehiscence mechanisms in the old herbarium material he had at hand for investigation. However, the fresh collections of the newly described M. quercinum indicate dehiscence by a rupture of the ascus apex.

Remarkably, Mycosphaerangium and Neomelanconium show some similarities to Cenangium ferruginosum, which also has erumpent apothecia, inamyloid asci, and ascospores with a gel sheath. In addition, the VBs that are characteristic of many members of the family are absent in Cenangium and in Mycosphaerangium. However, in the phylogenetic analyses, Cenangium is not closely related to Mycosphaerangium and Neomelanconium, indicating an independent evolutionary origin of these similarities.

Ecologically, Mycosphaerangium and Neomelanconium fit well the Cenangiaceae by growth on corticated branches still attached to the trees, which requires adaptations to drought. Colonization of aerial host parts (twigs or leaves) is a common ecological character of Cenangiaceae, which is connected with longevity and drought resistance of their apothecia (Pärtel et al. 2017). Therefore, morphological characters like rupture of the ascus apex and thick-walled, dark brown ascospores and conidia surrounded by a thick gel sheath may represent an adaptation to the dry conditions in their habitats.

Acknowledgements We thank the herbarium curators of FH, GAM, GZU, NY, and W for loan of herbarium specimens, Walter Till (WU) for handling the herbarium loans, Irmgard Greilhuber and Walter Till (WU) for incorporating the specimens in the herbarium and Arold Lavoie for sending a recent Canadian collection of Mycosphaerangium tetrasporum.

Funding Open access funding provided by Austrian Science Fund (FWF). The financial support by the Austrian Science Fund (FWF; project $\mathrm{P} 27645-\mathrm{B} 16$ ) to HV is gratefully acknowledged.

Open Access This article is licensed under a Creative Commons Attribution 4.0 International License, which permits use, sharing, adaptation, distribution and reproduction in any medium or format, as long as you give appropriate credit to the original author(s) and the source, provide a link to the Creative Commons licence, and indicate if changes were made. The images or other third party material in this article are included in the article's Creative Commons licence, unless indicated otherwise in a credit line to the material. If material is not included in the article's Creative Commons licence and your intended use is not permitted by statutory regulation or exceeds the permitted use, you will need to obtain permission directly from the copyright holder. To view a copy of this licence, visit http://creativecommons.org/licenses/by/4.0/.

\section{References}

Baral HO (1992) Vital versus herbarium taxonomy: morphological differences between living and dead cells of Ascomycetes, and their taxonomic implications. Mycotaxon 44:333-390

Barr ME (1978) The Diaporthales of North America. Mycol Mem 7:1232

Carbone I, Kohn LM (1999) A method for designing primer sets for speciation studies in filamentous ascomycetes. Mycologia 91:553556

Cash EK (1940) A second note on Georgia discomycetes. J Wash Acad Sci 30:299-305

Crous PW, Schumacher RK, Wood AR, Groenewald JZ (2019) The genera of fungi - G5: Arthrinium, Ceratosphaeria, Dimerosporiopsis, Hormodochis, Lecanostictopsis, Lembosina, Neomelanconium, Phragmotrichum, Pseudomelanconium, Rutola, and Trullula. Fungal Syst Evol 5:77-98

Galán R, Checa J, Blanco MN, Platas G, Tena R, Tello S, Hermosilla CE, Jaklitsch WM, Voglmayr H (2015) Taxonomic position of the genus Bicornispora and the appearance of a new species Bicornispora seditiosa. Mycologia 107:793-807

Hall TA (1999) BioEdit: a user-friendly biological sequence alignment editor and analysis program for Windows 95/98/NT. Nucleic Acids Symp Ser 41:95-98

Hofstetter V, Miądlikowska J, Kauff F, Lutzoni F (2007) Phylogenetic comparison of protein-coding versus ribosomal RNA-coding sequence data: a case study of the Lecanoromycetes (Ascomycota). Mol Phylogenet Evol 44:412-426

de Hoog GS, Gerrits van den Ende AHG (1998) Molecular diagnostics of clinical strains of filamentous basidiomycetes. Mycoses 41:183-189

Jaklitsch WM (2009) European species of Hypocrea part I. the greenspored species. Stud Mycol 63:1-91

Jaklitsch WM, Baral HO, Lücking R, Lumbsch HT (2016) Syllabus of plant families - A. Engler's Syllabus der Pflanzenfamilien part 1/2: Ascomycota, $13^{\text {th }}$ edn. Borntraeger, Stuttgart

Jaklitsch WM, Voglmayr H (2020) The genus Melanconis (Diaporthales). MycoKeys 63:69-117

Johnston PR, Quijada L, Smith CA, Baral HO, Hosoya T, Baschien C, Pärtel K, Zhuang WY, Haelewaters D, Park D, Carl S, LópezGiráldez F, Wang Z, Townsend JP (2019) A multigene phylogeny toward a new phylogenetic classification of Leotiomycetes. IMA Fungus 10:1

Katoh K, Misawa K, Kuma K, Miyata T (2002) MAFFT: a novel method for rapid multiple sequence alignment based on fast Fourier transform. Nucleic Acids Res 30:3059-3066

Katoh K, Rozewicki J, Yamada KD (2019) MAFFT online service: multiple sequence alignment, interactive sequence choice and visualization. Brief Bioinform 20:1160-1166

Kauff F, Lutzoni F (2002) Phylogeny of Gyalectales and Ostropales (Ascomycota, Fungi): among and within order relationships based on nuclear ribosomal RNA small and large subunits. Mol Phylogenet Evol 25:138-156

Madeira F, Park YM, Lee J, Buso N, Gur T, Madhusoodanan N, Basutkar P, Tivey ARN, Potter SC, Finn RD, Lopez R (2019) The EMBLEBI search and sequence analysis tools APIs in 2019. Nucleic Acids Res 47(W1):W636-W641

Pärtel K, Baral HO, Tamm H, Põldmaa K (2017) Evidence for the polyphyly of Encoelia and Encoelioideae with reconsideration of respective families in Leotiomycetes. Fungal Divers 82:183-219

Pärtel K, Põldmaa K (2019) First report of the anamorph of Encoelia furfuracea (Leotiomycetes) supports the recent merge of Cenangiaceae and Hemiphacidiaceae. Nova Hedwigia 108:217-226

Perić B, Baral HO, Pärtel K (2019) A new combination and new species in the genus Cenangiopsis (Helotiales): C. alpestris comb. nov. and C. andreae sp. nov. Mycologia Montenegrina 20:41-65 
Petrak F (1940) Mykologische Notizen XIII. Ann Mycol 38:181-267

Petrak F (1954) Über eine neue, westafrikanische Art der Gattung Neomelanconium Petr. Sydowia 8:51-53

Rossman AY, Adams GC, Cannon PF, Castlebury LA, Crous PW, Gryzenhout M, Jaklitsch WM, Mejia LC, Stoykov D, Udayanga D, Voglmayr H, Walker DM (2015) Recommendations of generic names in Diaporthales competing for protection or use. IMA Fungus 6:145-154

Seaver FJ (1951) The North American cup-fungi (Inoperculates). New York, pp 308-310, plates 132-133

Silvestro D, Michalak I (2012) raxmlGUI: a graphical front-end for RAxML. Org Divers Evol 12:335-337

Stamatakis E (2006) RAxML-VI-HPC: maximum likelihood-based phylogenetic analyses with thousands of taxa and mixed models. Bioinformatics 22:2688-2690

Sutton BC (1964) Melanconium link ex fries. Persoonia 3:193-198

Sutton BC (1980) The Coelomycetes: fungi imperfecti with pycnidia, acervuli, and stromata. Commonwealth Mycological Institute, Kew

Swofford DL (2002) PAUP* 4.0b10: phylogenetic analysis using parsimony (*and other methods). Sinauer, Sunderland

Stiller JW, Hall BD (1997) The origin of red algae: implications for plastid evolution. Proc Natl Acad Sci U S A 94:4520-4525

Thiers B (2020) Index Herbariorum: a global directory of public herbaria and associated staff. New York Botanical Garden's Virtual Herbarium. http://sweetgum.nybg.org/ih/. Accessed 20 July 2020

Triebel D, Scholz P (2020) IndExs - index of Exsiccatae. Botanische Statssammlung München. http://indexs. botanischestaatssammlung.de/. Accessed 20 July 2020

Turland NJ, Wiersema JH, Barrie FR, Greuter W, Hawksworth DL, Herendeen PS, Knapp S, Kusber WH, Li DZ, Marhold K, May TW, McNeill J, Monro AM, Prado J, Price MJ, Smith GF (2018) International Code of Nomenclature for algae, fungi, and plants (Shenzhen Code) adopted by the Nineteenth International Botanical Congress Shenzhen, China, July 2017. Regnum Vegetabile 159. Koeltz Botanical Books, Glashütten

Verkley GJM (1999) A monograph of the genus Pezicula and its anamorphs. Stud Mycol 44:1-180
Vilgalys R, Hester M (1990) Rapid genetic identification and mapping of enzymatically amplified ribosomal DNA from several Cryptococcus species. J Bacteriol 172:4238-4246

Voglmayr H, Akulov OY, Jaklitsch WM (2016) Reassessment of Allantonectria, phylogenetic position of Thyronectroidea, and Thyronectria caraganae sp. nov. Mycol Prog 15:921

Voglmayr H, Jaklitsch WM (2008) Prosthecium species with Stegonsporium anamorphs on Acer. Mycol Res 112:885-905

Voglmayr H, Jaklitsch WM (2011) Molecular data reveal high host specificity in the phylogenetically isolated genus Massaria (Ascomycota, Massariaceae). Fungal Divers 46:133-170

Voglmayr H, Rossman AY, Castlebury LA, Jaklitsch W (2012) Multigene phylogeny and taxonomy of the genus Melanconiella (Diaporthales). Fungal Divers 57:1-44

Wijayawardene NN, Hyde KD, Wanasinghe DN, Papizadeh M, Goonasekara ID, Camporesi E, Bhat DJ, McKenzie EHC, Phillips AJL, Diederich P, Tanaka K, Li WJ, Tangthirasunun N, Phookamsak R, Dai DQ, Dissanayake AJ, Weerakoon G, Maharachchikumbura SSN, Hashimoto A, Matsumura M, Bahkali AH, Wang Y (2016) Taxonomy and phylogeny of dematiaceous coelomycetes. Fungal Divers 77:1-316

Werle E, Schneider C, Renner M, Völker M, Fiehn W (1994) Convenient single-step, one tube purification of PCR products for direct sequencing. Nucleic Acids Res 22:4354-4355

White TJ, Bruns T, Lee S, Taylor J (1990) Amplification and direct sequencing of fungal ribosomal RNA genes for phylogenetics. In: Innis MA, Gelfand DH, Sninsky JJ, White TJ (eds) PCR protocols: a guide to methods and applications. Academic Press, San Diego, pp 315-322

Zimmermann H (1913) Verzeichnis der Pilze aus der Umgebung von Eisgrub. 2. Teil. Verh Naturf Ver Brünn 52:66-128

Publisher's note Springer Nature remains neutral with regard to jurisdictional claims in published maps and institutional affiliations. 